\title{
Inflation risk and international asset returns
}

\author{
Gerard A. Moerman ${ }^{\mathrm{a}}$, Mathijs A. van Dijk ${ }^{\mathrm{b}, *}$ \\ ${ }^{a}$ AEGON Asset Management and Rotterdam School of Management, Erasmus University \\ ${ }^{\mathrm{b}}$ Rotterdam School of Management, Erasmus University
}

This version: 19 September 2009

\begin{abstract}
We show that inflation risk is priced in international asset returns. We analyze inflation risk in a framework that encompasses the International Capital Asset Pricing Model (ICAPM) of Adler and Dumas (1983). In contrast to the extant empirical literature on the ICAPM, we relax the assumption that inflation rates are constant. We estimate and test a conditional version of the model for the G5 countries (France, Germany, Japan, the U.K., and the U.S.) over the period 1975-1998 and find evidence of statistically and economically significant prices of inflation risk (in addition to priced nominal exchange rate risk). Our results imply a rejection of the restrictions imposed by the ICAPM. In an extension of our analysis to 2003, we show that even after the termination of nominal exchange rate fluctuations in the euro area in 1999, differences in inflation rates across countries entail non-trivial real exchange rate risk premia.

JEL classification: C32 ; F30 ; G12

Keywords: International asset pricing; Inflation risk; Exchange rate risk

* Corresponding author. Tel.: +31 10408 1124; fax: +31 104089017

E-mail addresses: gmoerman@aegon.nl (G.A. Moerman), madijk@rsm.nl (M.A. van Dijk).

We thank Ike Mathur (the editor), an anonymous referee, Geert Bekaert, Ines Chaieb, Hans Dewachter, Frank de Jong, Bernard Dumas, Michael Ehrmann, Gregory Gadzinski, Ben Jacobsen, Erik Kole, Ronald Mahieu, Wessel Marquering, Robert Savickas, René Stulz, Marno Verbeek, and seminar participants at Ohio State University, the 2004 Erasmus Finance Day, the 2006 Washington Area Finance Association Meetings, and the Autumn 2006 Inquire Europe Meeting for helpful suggestions and discussion. Mathijs van Dijk is grateful for the hospitality of the Department of Finance at the Fisher College of Business (Ohio State University), where some of the work on this paper was performed. The opinions expressed in this article are those of the authors and do not necessarily represent those of AEGON Nederland N.V.
\end{abstract}




\section{Introduction}

As investors are concerned with asset returns expressed in real terms, uncertainty about inflation is a potentially important source of risk. Since the work of Bodie (1976) and Fama and Schwert (1977), a large literature has developed studying whether various asset classes provide a hedge against inflation. Furthermore, a substantial body of research analyzes inflation risk premia in bond returns (e.g., Evans, 1998; Buraschi and Jiltsov, 2005; Ang and Bekaert, 2008; Joyce, Lildholdt, and Sorensen, 2009). However, the issue whether inflation is a priced risk factor in stock returns has received little attention. Theoretical research by Elton, Gruber, and Rentzler (1983) and Stulz (1986) analyzes the impact of inflation on stock returns in domestic asset pricing models. Empirical work by Chen, Roll, and Ross (1986) and Ferson and Harvey (1991) shows that, among other economic risk factors, expected and unexpected inflation capture some of the variation in returns on portfolios of U.S. equities in a domestic asset pricing context.

It is natural to investigate the impact of inflation risk on asset prices in an international context. Inflation risk may be at least partially diversifiable internationally. Moreover, theoretical international asset pricing models suggest a close link between inflation risk and exchange rate risk. However, the extant literature on international asset pricing commonly assumes inflation rates to be constant. ${ }^{1}$ In this paper, we adopt a global perspective and estimate the prices of risk related to the inflation rates in various individual countries using data on international stock returns. Our approach has its foundation in theoretical asset pricing models, as opposed to an empirically inspired multifactor model. The methodology we employ not only enables us to test the conditional version of asset pricing models, but also takes account of important characteristics

\footnotetext{
1 The few empirical asset pricing papers that do incorporate inflation risk draw on empirically motivated factor models and merely examine inflation risk factors aggregated over many countries, jointly with a substantial number of other global economic risk variables, and/or in an unconditional framework. See, e.g., Ferson and Harvey (1993, 1994) and Vassalou (2000).
} 
of asset returns (such as heteroskedasticity) that other studies leave unmodeled. And since we estimate a fully parameterized model, we can recover the time-varying risk premia of market, exchange rate, and inflation risk in asset returns.

International asset pricing models study how expected asset returns are formed when investors differ in their country of residence. When investors from different countries have identical investment and consumption opportunity sets, we can straightforwardly generalize the domestic Capital Asset Pricing Model (CAPM) to an International CAPM (ICAPM) in which the global market portfolio is the only priced risk factor (see Grauer, Litzenberger, and Stehle, 1976). When purchasing power parity (PPP) does not hold, however, investors from different countries have different consumption opportunity sets. ${ }^{2}$ Consequently, investors evaluate the (real) returns from the same security differently. In that case, the market portfolio is no longer the only priced risk factor. In the ICAPM of Adler and Dumas (1983), asset returns depend on their covariance with both global market returns and exchange rate returns. Other international asset pricing models under heterogeneous consumption opportunity sets are developed by Solnik (1974), Sercu (1980), and Stulz (1981). ${ }^{3}$

Empirical evidence indicates that exchange rate risk is priced in international asset returns. Dumas and Solnik (1995) estimate a conditional ICAPM and report evidence of exchange rate risk premia in the returns on the stock markets of Germany, Japan, the U.K., and the U.S. over the period 1970-1991. De Santis and Gérard (1998) employ a more comprehensive econometric methodology to test the ICAPM for the same four countries over the period 19731994. Their analysis supports a conditional ICAPM that includes both global market risk and three currency risk factors related to the German mark, the Japanese yen, and the British pound.

2 Deviations from PPP occur either because of differences in preferences across countries or due to deviations from the law of one price. We refer to Adler and Dumas (1983) for an exposition of this point.

3 See Dumas (1994) and Stulz (1995) for an overview of international asset pricing. 
However, these studies exclusively test the version of the ICAPM developed by Solnik (1974) and Sercu (1980). Their model is a special case of the Adler and Dumas (1983) model in which all domestic inflation rates expressed in local currency are assumed to be non-stochastic. Consequently, the real exchange rate risk factors in the ICAPM of Adler and Dumas (1983) are replaced by nominal exchange rate risk factors in the Solnik-Sercu model. The implications of the restriction that inflation rates are constant have not been investigated to date. While inflation rates are known to be substantially less volatile than nominal exchange rates at short horizons, it is not obvious that this implies that uncertainty about future inflation is relatively unimportant to investors. (It is also unclear what this simplification buys, as the literature on measuring inflation is well-developed.)

As highlighted by, e.g., Brennan and Xia (2002), Campbell and Viceira (2001), and Campbell, Chan, and Viceira (2003), uncertainty about inflation plays a central role in dynamic asset allocation decisions, especially for long-term investors. Moreover, hedging inflation risk is significantly more complicated than hedging exchange rate risk. Hence, expected asset returns may well contain non-negligible inflation risk premia. Furthermore, the ICAPM of Solnik-Sercu neglects the possibility that real exchange rate risk is priced when nominal exchange rate fluctuations are absent. For example, nominal exchange rate fluctuations within the European Economic and Monetary Union (EMU) ceased to exist at the introduction of the euro in 1999. However, European inflation risk may still be priced in asset returns.

Our contribution is four-fold. First, our paper is among the first to test the ICAPM of Adler and Dumas (1983) with real exchange rate risk factors. ${ }^{4}$ Second, we investigate whether the

\footnotetext{
4 Carrieri, Errunza, and Majerbi (2006) also examine whether real exchange rate risk is priced. However, they employ exchange rate indices and hence deviate from the theoretical setting of Adler and Dumas (1983). In addition, they focus on the exchange rate risk of emerging markets, for which the assumption of constant inflation is clearly violated. Our study demonstrates the importance of risk factors related to uncertain inflation in developed capital markets.
} 
distinction between real and nominal exchange rates matters for the inferences drawn from international asset pricing tests. We show that prices of risk related to some currencies are no longer significant when real instead of nominal exchange rates are used as risk factors, indicating that previous studies overstate the significance of currency risk. Third, these findings suggest that inflation risk partially offsets nominal exchange rate risk and raise the question whether inflation risk constitutes a distinct source of priced risk. In the model of Adler and Dumas (1983), the prices of inflation and nominal exchange rate risk are restricted to be equal. Relaxing this restriction leads to a model in which asset returns depend on their sensitivity to both inflation risk and nominal exchange rate risk. Our approach allows for an assessment of the significance of inflation risk premia and offers a new empirical test of the ICAPM. Our results indicate that (i) inflation risk is an important and independent priced risk factor in international asset returns and (ii) we can reject the restrictions imposed by the ICAPM of Adler and Dumas (1983). Fourth, we examine whether real exchange rate risk is priced within the euro area after 1999.

We estimate and test a conditional version of the ICAPM of Adler and Dumas (1983) for the equity markets of France, Germany, Japan, the U.K., and the U.S. Our main analyses concern the period 1973-1998, since the nominal exchange rate of the French franc versus the German mark experiences an abrupt structural break at the introduction of the euro in 1999. In the second part of the paper, we extend the sample period to 2003 to examine the impact of the introduction of the euro on the importance of inflation risk.

Following De Santis and Gérard (1998), we employ a parsimonious multivariate GARCH process to test the pricing implications of the model. We confirm the results of previous studies that the (time-varying) prices of nominal exchange rate risk related to all four exchange rates in the sample are significantly different from zero. However, the prices of real exchange rate risk are only significant for the exchange rates of Germany versus Japan and the U.K. This result implies 
that the choice of real versus nominal exchange rates matters in international asset pricing tests. Relaxing the restriction that the prices of nominal exchange rate risk and inflation risk are equal, we report evidence in favor of priced inflation risk for all countries in the sample (in addition to significant prices of risk for all four nominal exchange rates). We reject the hypotheses that the prices of inflation risk are constant over time and that they are equal to zero. We show that inflation risk is not only statistically significant, but also has an economically important contribution to expected international asset returns. Inflation risk premia in asset returns are generally of the same order of magnitude as nominal exchange rate risk premia.

An interesting application of the model concerns the post-euro period. Although nominal exchange rate fluctuations were terminated within the euro area in 1999, differences in inflation may entail nontrivial real exchange rate risk. An analysis of the equity markets of France, Germany, Japan, the U.K., and the U.S. over the period 1973-2003 indicates that the risk premium related to the German-French inflation differential is still important in the post-euro period. This finding suggests that even for closely integrated countries with a common currency, investors demand a risk premium for their exposure to inflation risk.

\section{The model}

Our study starts out with the ICAPM of Adler and Dumas (1983). We can construct the model as follows. Consider a world economy with $L+1$ countries (currencies), numbered $l=0,1, \ldots, L$, with currency 0 as the measurement or numeraire currency. Apart from the measurement currency deposit, there are $M=N+L+1$ securities, comprising of $N$ equities or portfolios of equities, $L$ non-measurement currency deposits, and the world portfolio of equities which is the $M^{\text {th }}$ and last security. All returns are expressed in the numeraire currency and in excess of the risk-free rate, which corresponds to the short-term deposit rate in the numeraire currency. We can 
express the pricing restrictions on asset $i$ imposed by the conditional version of the ICAPM of Adler and Dumas (1983) as follows:

$$
E\left[r_{i t} \mid \Omega_{t-1}\right]=\delta_{m, t-1} \operatorname{cov}\left[r_{i t}, r_{m t} \mid \Omega_{t-1}\right]+\sum_{l=0}^{L} \delta_{l, t-1} \operatorname{cov}\left[r_{i t}, \pi_{l 0 t} \mid \Omega_{t-1}\right] \quad i=1, \ldots, M
$$

where

$$
\delta_{m, t-1}=\theta_{t-1} \equiv \frac{1}{\sum_{l=0}^{L} \frac{W_{l, t-1}}{W_{t-1}} \times \frac{1}{\theta_{l}}} \quad \text { and } \quad \delta_{l, t-1}=\theta_{t-1}\left(\frac{1}{\theta_{l}}-1\right) \frac{W_{l, t-1}}{W_{t-1}}
$$

In equation (1), $r_{i t}$ denotes the nominal return on security or portfolio $i$ from time $t-1$ to $t$ in excess of the risk-free rate, $\Omega_{t-1}$ is the information set that investors use in choosing their portfolios, $r_{m t}$ is the nominal return on the world market portfolio in excess of the risk-free rate, and $\pi_{l 0 t}$ is the domestic inflation rate of country $l$ measured in the numeraire currency. We can decompose these domestic inflation rates as $\pi_{l 0 t}=s_{l t}+\pi_{l t}$, where $s_{l t}$ denotes the nominal exchange rate change of currency $l$ in terms of currency 0 and $\pi_{l t}$ is the domestic inflation rate of country $l$ measured in currency $l$ from time $t-1$ to $t$. Furthermore, $\theta_{l}$ is the coefficient of relative risk aversion for investors from country $l, \theta_{t-1}$ is an average of the risk aversion coefficients of all countries, weighted by its relative wealth at time $t-1$ as represented by $W_{l, t-1} / W_{t-1}$. Dumas and Solnik (1995) refer to the time-varying coefficient $\delta_{m, t-1}$ in equation (1) as the "world price of market risk" and to the time-varying coefficients $\delta_{l, t-1}$ as the "world prices of exchange rate risk."

The ICAPM of Solnik (1974) and Sercu (1980) is a special case of equation (1). The Solnik-Sercu model imposes the assumption that the domestic inflation rates expressed in local currency $\pi_{l t}(l=0,1, \ldots, L)$ are non-stochastic. Therefore, the $L+1$ covariance terms in equation (1) collapse into $L$ covariance terms with the nominal exchange rates. Studies that empirically test the ICAPM (e.g., Dumas and Solnik, 1995; De Santis and Gérard, 1998) also adopt the restriction 
that inflation rates are constant over time. We are not aware of any research on the validity of this restriction. When we relax the assumption that inflation rates are non-stochastic and only assume that the domestic inflation rate in the numeraire country (expressed in the numeraire currency) is constant, we obtain an intuitively appealing version of the ICAPM:

$$
E\left[r_{i t} \mid \Omega_{t-1}\right]=\delta_{m, t-1} \operatorname{cov}\left[r_{i t}, r_{m t} \mid \Omega_{t-1}\right]+\sum_{l=1}^{L} \delta_{l, t-1} \operatorname{cov}\left[r_{i t}, q_{l t} \mid \Omega_{t-1}\right] \quad i=1, \ldots, M,
$$

where $q_{l t} \equiv \pi_{l 0 t}-\pi_{0 t}=s_{l t}+\pi_{l t}-\pi_{0 t}$ is the real exchange rate change of currency $l$ in terms of currency $0 .^{5}$ Hence, this version of the ICAPM incorporates the world price of market risk and $L$ "world prices of real exchange rate risk." The model in equation (2) is less restrictive than the Solnik-Sercu version of the ICAPM and allows for the possibility of priced real exchange rate risk when nominal exchange rates are fixed.

The covariance between $r_{i t}$ and $q_{l t}$ reflects two sources of risk that may be independent: nominal exchange rate risk and inflation risk. An interesting research issue is the relative importance of these risk factors. A related question is whether they reinforce each other or (partially) cancel each other out. The distinction between these two separate sources of risk may become especially relevant when we study inflation risk in the euro area. Within the euro area, real exchange rate risk contains both the nominal exchange rate and inflation risk components before the introduction of the euro in 1999 and only the inflation risk component after 1999. If inflation risk is priced in international asset returns, this is also likely to constitute a relevant priced risk factor in the post-euro era. Therefore, we extend the model specified in equation (2) by allowing the prices of nominal exchange rate risk and inflation risk to differ:

\footnotetext{
5 Note that the number of risk premia in this model is reduced to $L$, as this approach assumes the domestic inflation rate in the numeraire country to be non-stochastic. Without loss of generality, we can subtract this inflation rate from the domestic inflation rates of the other $L$ countries expressed in the numeraire currency.
} 


$$
\begin{aligned}
E\left[r_{i t} \mid \Omega_{t-1}\right]=\delta_{m, t-1} & \operatorname{cov}\left[r_{i t}, r_{m t} \mid \Omega_{t-1}\right]+\sum_{l=1}^{L} \varphi_{l, t-1} \operatorname{cov}\left[r_{i t}, s_{l t} \mid \Omega_{t-1}\right] \\
& +\sum_{l=1}^{L} \gamma_{l, t-1} \operatorname{cov}\left[r_{i t},\left(\pi_{l t}-\pi_{0 t}\right) \mid \Omega_{t-1}\right] \quad i=1, \ldots, M
\end{aligned}
$$

We refer to the time-varying coefficients $\varphi_{l, t-1}$ as the world prices of nominal exchange rate risk and to $\gamma_{l, t-1}$ as the "world prices of inflation risk." We present estimates and tests of this model in section 5. This specification allows for an alternative statistical test of the ICAPM of Adler and Dumas (1983). A rejection of the hypothesis that $\varphi_{l, t-1}$ and $\gamma_{1, t-1}$ are equal implies evidence against the restrictions imposed by the ICAPM. Finally, a natural extension of model (3) concerns the case in which the assumption that the domestic inflation rate in the numeraire country is constant is also dropped, which leads to the following expression for expected returns:

$$
\begin{array}{r}
E\left[r_{i t} \mid \Omega_{t-1}\right]=\delta_{m, t-1} \operatorname{cov}\left[r_{i t}, r_{m t} \mid \Omega_{t-1}\right]+\sum_{l=1}^{L} \varphi_{l, t-1} \operatorname{cov}\left[r_{i t}, s_{l t} \mid \Omega_{t-1}\right] \\
+\sum_{l=0}^{L} \rho_{l, t-1} \operatorname{cov}\left[r_{i t}, \pi_{l t} \mid \Omega_{t-1}\right] \quad i=1, \ldots, M
\end{array}
$$

Note that the $L$ prices of risk $\gamma_{1, t-1}$ in equation (3) have been replaced by $L+1$ prices of inflation risk $\rho_{l, t-1}$ in equation (4).

Although our empirical estimation and tests of these models allows for time-series variation in the prices of risk as well as the covariances, the models of Adler and Dumas (1983) Solnik (1974) and Sercu (1980) ignore intertemporal hedging. Chang, Errunza, Hogan, and Hung (2005) and $\mathrm{Ng}$ (2004) both present an international version of the domestic intertemporal CAPM (see, e.g., Campbell, 1993). However, neither of these studies estimates separate inflation risk premia for the assets included in their empirical analysis. We leave the estimation of an international intertemporal CAPM with separate exchange rate risk and inflation risk factors for individual countries for future research. 


\section{Empirical methodology}

We are interested in estimating the conditional version of models (2), (3), and (4). We employ the parsimonious multivariate generalized autoregressive conditionally heteroskedastic (GARCH) approach of De Santis and Gérard $(1997,1998) .{ }^{6}$ Our starting point is the conditional ICAPM with real exchange rate risk factors in equation (2). This equation states the moment conditions for the excess returns of the assets under consideration. Adding a disturbance term orthogonal to the information available at the end of time $t-1$ yields the econometric representation of the model that we can use to estimate the risk premia:

$$
r_{t}=\delta_{m, t-1} h_{m, t}+\sum_{l=1}^{L} \delta_{l, t-1} h_{n+l, t}+\varepsilon_{t} \quad \varepsilon_{t} \mid \Omega_{t-1} \sim N\left(0, H_{t}\right),
$$

where $H_{t}$ is the $(M \times M)$ covariance matrix of the excess returns at time $t$ and $h_{i, t}$ is the $i^{\text {th }}$ column of $H_{t}$. The world prices of market and real exchange rate risk are time-varying and are functions of a number of instrumental variables $Z_{t-1}$ that represent the information set $\Omega_{t-1}$.

If all investors are risk averse, the world price of market risk is positive (see equation (1)). Following De Santis and Gérard (1997), we force the price of market risk to satisfy this restriction by modeling the risk premium as an exponential function of the information variables. We do not restrict the real exchange rate risk premia to be positive and hence we model the prices of real exchange rate risk as a linear function of the information variables:

$$
\begin{aligned}
& \delta_{m, t-1}=\exp \left(\kappa_{m}^{\prime} \cdot Z_{t-1}\right) \\
& \delta_{l, t-1}=\kappa_{l}^{\prime} \cdot Z_{t-1} \quad l=1, \ldots, L
\end{aligned}
$$

We provide details on the instrumental variables used in the data section.

\footnotetext{
6 This methodology has been widely adopted in the literature, see e.g. Carrieri (2001), Carrieri, Errunza, and
} Majerbi (2006), De Santis, Gérard, and Hillion (2003), and Chaieb and Errunza (2007). 
An important and well-documented characteristic of security returns is the heteroskedasticity in their innovations. We have to take this feature into account when estimating the world prices of risk. Therefore, we follow the approach of De Santis and Gérard $(1997,1998)$ by imposing a diagonal GARCH process on the conditional second moments of the assets. In other words, the variance in $H_{t}$ depends only on past squared residuals and an autoregressive component, while the covariances depend on past cross-products of residuals and an autoregressive component. Furthermore, we assume that the process is covariance stationary. We can then write the process for $H_{t}$ as follows:

$$
H_{t}=H_{0} *\left(l l^{\prime}-a a^{\prime}-b b^{\prime}\right)+a a^{\prime} * \varepsilon_{t-1} \varepsilon_{t-1}^{\prime}+b b^{\prime} * H_{t-1}
$$

where $H_{0}$ is the unconditional variance-covariance matrix of the residuals, $l$ is a $(M \times 1)$ vector of ones, $a$ and $b$ are $(M \times 1)$ vectors containing the unknown parameters and $*$ denotes the Hadamard product (element by element matrix multiplication). $H_{0}$ is not directly observable, but we can estimate $H_{0}$ consistently using the iterative procedure developed by De Santis and Gérard (1997). In the first iteration of this estimation procedure, we set $H_{0}$ equal to the sample covariance matrix of the returns. In subsequent steps, we update $H_{0}$ using the estimated residuals at the end of the previous iteration. For a detailed discussion of the properties of the GARCH parameterization we refer to De Santis and Gérard (1997). ${ }^{7}$

Under the assumption that the errors are conditionally normally distributed, we can express the log-likelihood function as follows:

$$
\ln L(\Psi)=-\frac{T M}{2} \ln 2 \pi-\frac{1}{2} \sum_{t=1}^{T} \ln \left|H_{t}(\Psi)\right|-\frac{1}{2} \sum_{t=1}^{T} \varepsilon_{t}(\Psi)^{\prime} H_{t}(\Psi)^{-1} \varepsilon_{t}(\Psi)
$$

\footnotetext{
7 A possible extension of this methodology would be to add an asymmetric component in the variance equation, see, e.g., Engle and Ng (1993), Glosten, Jagannathan, and Runkle (1993), Kroner and Ng (1998), Bekaert and Wu (2000), and Mazzotta (2008). However, introducing asymmetries in the volatility dynamics in our methodology would increase the number of parameters to be estimated substantially, which would seriously hamper our estimation procedure.
} 
where $\Psi$ is the vector of all unknown parameters. We use quasi-maximum likelihood (QML) standard errors obtained with the estimation methodology proposed by Bollerslev and Wooldridge (1992), because the restriction of conditional normality is often violated.

We also employ the model parameterization described above for the model that incorporates nominal exchange rate and inflation risk factors separately (equation (3)). We can express the econometric specification of this model as follows:

$$
r_{t}=\delta_{m, t-1} h_{m, t}+\sum_{l=1}^{L} \varphi_{l, t-1} h_{n+l, t}+\sum_{l=1}^{L} \gamma_{l, t-1} h_{n+L+l, t}+\eta_{t} \quad \eta_{t} \mid \Omega_{t-1} \sim N\left(0, H_{t}\right)
$$

where the process for $H_{t}$ is given in equation (8). We model the risk premia as a function of the instrumental variables $Z_{t-1}$ in the following way:

$$
\begin{aligned}
& \delta_{m, t-1}=\exp \left(\kappa_{m}^{\prime} \cdot Z_{t-1}\right) \\
& \varphi_{l, t-1}=\lambda^{\prime} \cdot Z_{t-1} \quad l=1, \ldots, L \\
& \gamma_{l, t-1}=\mu_{l}^{\prime} \cdot Z_{t-1} \quad l=1, \ldots, L
\end{aligned}
$$

The econometric specification of model (4) follows equations (10) through (13), where we replace the $L$ prices of risk related to inflation rates in excess of the numeraire inflation $\gamma_{1, t-1}$ by $L+1$ prices of risk related to the inflation rates of all individual countries $\rho_{l, t-1}$.

\section{Data}

We use monthly returns on stock indices for the G5 countries (France, Germany, Japan, the U.K., and the U.S.) in addition to a value-weighted world index over the period 1975:01-1998:12. For our analysis of the post-euro period we extend our sample period to 2003:12. The main reason for not using the full sample period in most of our analyses is that there is an abrupt structural break in the nominal exchange rate of the French franc versus the German mark at the introduction of 
the euro in 1999. In unreported analyses, we find that our main results are similar when we leave out France and analyze Germany, Japan, the U.K., and the U.S. over the period 1975-2003.

We use Germany as the numeraire country, as this makes the results of the post-euro analysis easy to interpret. We obtain similar findings when we take the U.S. as the numeraire country. All stock index data are from Morgan Stanley Capital International (MSCI) and include dividends. Nominal end-of-period exchange rates against the U.S. dollar are from International Financial Statistics (IFS). Returns on both equity indices and exchange rates are discrete and expressed in terms of the German mark. We use consumer price index (CPI) data from IFS to compute year-on-year inflation rates. Using month-on-month inflation rates based on seasonally adjusted CPI indices or using CPI indices excluding food and energy does not materially affect the results. For the conditionally risk-free asset we take the return on the one-month euro-mark deposit quoted in London (extracted from Datastream). We compute monthly excess returns by subtracting the risk-free rate from the monthly return on each security.

The choice of instrumental variables is potentially very important in conditional tests of asset pricing models. However, the model does not provide any guidance as to the choice of the information variables and the number of instrumental variables is limited by the econometric methodology. Our selection of instruments builds on previous empirical research, notably Harvey (1991), Ferson and Harvey (1993), Dumas and Solnik (1995), and De Santis and Gérard (1997, 1998). We include the dividend yield on the world equity index (in excess of the risk-free rate), the U.S. default premium measured by the yield differential between Moody's Baa and Aaa rated bonds, and the change in the U.S. term premium calculated as the difference between the yield on 
the ten-year U.S. Treasury note and the Federal Funds Rate. ${ }^{8}$ The dividend yield is obtained from Datastream and the bond yields are taken from the website of the Federal Reserve System.

Table 1 presents summary statistics over the period 1975:01-1998:12. Panels A, B, and C present information on, respectively, the equity indices and the real exchange rates, the instrumental variables, and the nominal exchange rates and inflation differentials. The skewness and especially the kurtosis of the excess stock returns generally show large deviations from the values of the normal distribution. The distribution of the excess returns on the U.K. stock index in particular exhibits very fat tails, which is primarily due to several extreme returns in 1975 (also documented by De Santis and Gérard, 1998). The Jarque-Bera test clearly rejects the assumption of normally distributed returns for all series.

As is noted by a number of previous studies (e.g., Rogoff, 1996), inflation differentials are considerably less volatile than nominal exchange rates at the monthly horizon (see Panel C). Panel D of Table 1 contains the unconditional correlations between stock index returns and real exchange rate returns. Correlations among stock returns and among real exchange rates are all positive. Monthly stock returns and real exchange rates are generally negatively correlated. Correlations between stock returns and nominal exchange rate returns are negative and generally substantial, as indicated by Panel E. Stock returns do not strongly correlate with inflation differentials. Correlations between nominal exchange rate returns and inflation differentials are remarkably low, less than 0.1 in absolute value (with only one exception).

\footnotetext{
8 In line with De Santis and Gérard (1998), we also estimate our model with the change in yield on the one-month euro-dollar deposit as an additional instrumental variable. Our optimization procedure becomes considerably less efficient and hence we omit this specification. However, the inclusion of this instrument in the information set does not materially affect our estimation results and does not statistically improve our specification.
} 


\section{Empirical results}

We estimate and test four different international asset pricing models. We consider all model specifications in their conditional version and allow both prices of risk and covariances to vary over time. First, we analyze the ICAPM of Solnik (1974) and Sercu (1980) that assumes inflation rates to be non-stochastic and in which expected asset returns depend on their covariance with global market returns and nominal exchange rate returns. To save space, we do not report these results, but they are available from the authors. We confirm the findings of Dumas and Solnik (1995) and De Santis and Gérard (1998) that both the world price of market risk and the world price of nominal exchange rate risk for all four individual nominal exchange rates in the sample (versus the German mark) are time-varying and statistically significant. Second, in section 5.1 we examine the international asset pricing model in equation (2). This version of the ICAPM relaxes the assumption that domestic inflation rates expressed in local currency are non-stochastic, and asset returns depend on their covariance with the global market factor and four real exchange rate risk factors. Third, section 5.2 provides estimates and statistical tests of the model in equation (3). This model posits that asset returns depend on risk factors related to the global market portfolio, the four nominal exchange rates in the sample, as well as four inflation rates in excess of the numeraire inflation. Finally, section 5.3 discusses the results of the tests of the model in equation (4) that includes global market risk, four nominal exchange risk factors, and five inflation risk factors for each of the individual countries in the sample.

\subsection{Conditional ICAPM with real exchange rate risk}

Table 2 presents the estimation results for the ICAPM with real exchange rate risk - of which the empirical specification is given by equation (5) - over the period 1975:01-1998:12. Panel A of Table 2 shows the point estimates and the standard errors of the mean equation parameters and 
Panel B shows the estimates of the parameters in the conditional covariance equation. Both point estimates and standard errors are of the same order of magnitude as those reported by De Santis and Gérard (1998). Several of these parameters (all of the covariance process) are significant in isolation. More interesting, however, are the specification tests that assess the significance of a number of parameters simultaneously. For each of the five world prices of risk, we perform a likelihood-ratio test to investigate (i) whether the prices of risk are constant or time-varying and (ii) whether the prices of risk are significantly different from zero. We apply the tests to all prices of real exchange rate risk simultaneously as well as separately for each real exchange rate in the sample. The results are in Panel $\mathrm{C}$ of Table 2.

The first two tests in Panel $\mathrm{C}$ focus on the world price of market risk. This price of risk is significantly different from zero at the $1 \%$ significance level and we reject the hypothesis that the world price of market risk is constant at the $10 \%$ level, in line with the results of Dumas and Solnik (1995) and De Santis and Gérard (1998). The other tests in Panel C show that the prices of real exchange rate risk are jointly time-varying ( $p$-value of 0.016 ) and reject the hypothesis that the prices of real exchange rate risk are jointly equal to zero $(p=0.041)$.

The tests on the prices of individual real exchange rates reveal a striking difference between the models with nominal and real exchange rate risk factors. While in the former model all four individual nominal exchange rates carry significant prices of risk, we can only reject the hypothesis that real exchange risk is significant in the latter model for Japan $(p=0.008)$ and the U.K. $(p=0.029)$. The prices of the real exchange rates of the French franc and the U.S. dollar versus the German mark are not significant. We also reject the null-hypothesis that the prices of real exchange rate risk are constant for Japan and the U.K., but not for the other countries.

Previous empirical tests of the ICAPM assume that inflation rates are non-stochastic and hence only incorporate nominal exchange rate risk. The world prices of nominal exchange rate 
risk are typically highly significant in these studies. Table 2 shows, however, that the prices of real exchange rate risk related to France, and - more surprisingly - the U.S. are not significantly different from zero. These findings indicate that the assumption of constant inflation rates commonly made in the literature is not as innocuous as previously thought. The results of studies on exchange rate risk that ignore the stochastic nature of inflation can thus be misleading. Even in a sample of developed markets, nominal exchange rate risk appears to be priced, while corresponding real exchange rates do not bear significant prices of risk.

The prices of real exchange rate risk consist of two components: nominal exchange rate risk and inflation risk. Our findings in section 5.1 raise the question whether these components of the price of currency risk partially offset each other, notably for France and the U.S. To establish the sign and relative magnitude of inflation risk and nominal exchange rate risk premia, section 5.2 extends our analysis to include both sources of risk separately.

\subsection{Conditional asset pricing model with nominal exchange rate and inflation risk}

Table 3 presents the estimation and test results for the model specification in equation (10). Panel A (B) shows the estimates of the mean (variance) equation. The standard errors for the inflation risk factors are lower than the standard errors for the nominal exchange rate risk factors. Inflation risk factors also exhibit a high persistence as indicated by an estimate of $b$ that is very close to 1 . Panel $\mathrm{C}$ of Table 3 displays the results of the likelihood-ratio tests that assess the significance and time-variation of the prices of risk. In line with the results in Table 2, we reject the hypotheses that the price of market risk is constant over time and equal to zero. The prices of nominal exchange are also significantly different from zero, both jointly and for each individual nominal exchange rate in the sample. In contrast to our findings in Table 2 and in line with previous empirical research, French and U.S. currency risk thus also carry a significant price of risk in this 
model. The most striking results in Table 3, however, concern inflation risk. For all inflation risk factors (jointly and separately), we reject the hypothesis that their prices of risk are equal to zero at any conventional significance level. Despite the fact that the variance of the inflation differentials is substantially lower than the variance of the nominal exchange rates, inflation risk thus constitutes a significant priced risk factor in international stock returns. The tests also reject a specification of the model in which the prices of nominal exchange rate and inflation risk are constant. A likelihood-ratio test on the equality of the prices of nominal exchange rate and inflation risk assumes a value of 244.4 ( $p$-value $<0.001)$. Hence, we identify inflation risk as a distinct source of risk in international asset returns and we reject the restrictions imposed by the ICAPM of Adler and Dumas (1983). ${ }^{9}$

Figure 1 presents plots of three of the nine different prices of risk in this model specification over the period 1975-1998: the price of market risk, the price of U.S. nominal exchange rate risk, and the price of U.S. inflation risk. Note that the scaling differs across these graphs. (The plots of the other six prices of risk are available from the authors.) The graphs in Figure 1 also contain a line representing the average price of risk over the sample period as well as the Hodrick-Prescott filtered prices. The latter serve as an indication of the general trend over time, as the point estimates are subject to estimation error. All prices of risk exhibit substantial variation over time. The graph of the world price of market risk is very similar to Figure 1 of De Santis and Gérard (1998), with peaks in the mid 1970s, in the year 1980, and around 1983. The average price of market risk in our model is 0.075 , which is substantially higher than the estimate of De Santis and Gérard. The explanation for this difference lies in the fact that the prices of

\footnotetext{
9 Several colleagues have suggested that our results may be partially driven by the early part of our sample period, in which the capital markets of the countries in our sample were not completely integrated. To alleviate these concerns, we redo our analysis for the period after 1980 and obtain similar results. The enactment of the Foreign Exchange and Foreign Trade Control Law in Japan in December 1980 virtually eliminated Japanese capital controls, see Gultekin, Gultekin, and Penati (1989).
} 
inflation risk are generally negative in our sample. In the ICAPM without inflation risk factors, the world market portfolio partially absorbs this source of risk.

The graphs of the prices of nominal exchange rate risk also resemble the general patterns observed by De Santis and Gérard (1998). All individual currency risk factors seem to matter for international asset pricing. While the mean values are relatively close to zero, all four prices of risk attain considerable higher values in some periods and all assume both positive and negative values over the sample period.

The magnitude of the prices of inflation risk is noteworthy. Inflation risk prices are much larger than nominal exchange rate risk prices, especially for France and the U.S. (roughly by a factor 10). These large return compensations per unit of inflation risk are counterbalanced by very small covariances between asset returns and inflation risk factors. As a comparison, the unconditional covariance between German stock returns and the U.S. inflation risk factor is equal to 0.141 , while the covariance between German stock returns and the nominal dollar - mark exchange rate is 7.221. Nevertheless, the high prices per unit of inflation risk are likely to produce substantial inflation risk premia in asset returns.

To assess the economic significance of inflation and nominal exchange rate risk premia as well as the relative importance of these sources of priced risk, we decompose the expected asset returns in our sample into the risk premia related to market, currency, and inflation risk. We compute the premium for market risk for asset $i$ from time $t-1$ to $t$ as the product of the timevarying price of market risk $\delta_{m, t-1}$ and the conditional covariance $\operatorname{cov}\left[r_{i t}, r_{m t} \mid \Omega_{t-1}\right]$. Similarly, we compute the $l$ nominal exchange rate risk premia as $\varphi_{l, t-1} \times \operatorname{cov}\left[r_{i t}, s_{l t} \mid \Omega_{t-1}\right]$. The terms $\gamma_{l, t-1} \times$ $\operatorname{cov}\left[r_{i t}, \pi_{l t}-\pi_{0 t} \mid \Omega_{t-1}\right]$ for $l=1, \ldots, L$ provide an estimate of the inflation risk premia for asset $i$. Figure 2 depicts the development of the risk premia for the German equity index over time. The 
top panel presents the aggregate contributions of market, nominal exchange rate, and inflation risk to expected Germany stock returns. The middle and bottom panel depict individual nominal exchange rate and inflation risk premia related to France, Japan, the U.K., and the U.S. Note that the scaling of the middle and bottom panels is different from the top panel.

Global market risk is the dominant component of the total risk premium on Germany equity, amounting to around 90 basis points per month on average over the period 1975-1998. The aggregate premium for nominal exchange rate risk is generally negative. The average value computed over the entire sample is -0.104 . As the sample averages of conditional risk premia should approximate their unconditional values, an unconditional analysis of nominal exchange rate risk would probably indicate that the premium for currency risk is negligible. But the premium is markedly negative in most of the 1970s and 1990s and positive in the early and mid 1980s. The sample average of the absolute value of the premium is almost 20 basis points per month or roughly 2.4 percent per annum, while the premium occasionally reaches values of up to 70 basis points per month (both positive and negative). Moreover, the aggregate currency risk premium disregards possible offsetting effects across the four nominal exchange rates in the sample. The middle panel of Figure 2 demonstrates that the contribution of every individual nominal exchange rate is economically substantial for prolonged periods of time.

The top panel of Figure 2 clearly shows that the aggregate inflation risk premium in the returns in the MSCI Germany index is considerable over the period 1975-1998. The sample average of -4.6 basis points per month is relatively small, but the mean absolute value is equal to 26 basis points per month, which is even higher than the aggregate premium for currency risk. The aggregate inflation risk premium is negative for most of the 1970s and 1990s, but substantial and positive in the 1980s (averaging more than 30 basis points per month in the years 1982- 
1988). In the mid 1970s and 1980s the (aggregate) premia for inflation risk and nominal exchange rate risk generally have opposite signs, but both turn negative around 1990.

The bottom panel of Figure 2 illustrates the cross-sectional differences in inflation risk premia. The U.K. inflation premium assumes small negative values for almost the entire sample period. The inflation risk premium for Japan is positive in most months. The same holds for France, but the premium for inflation risk related to France is negative in 1975-1977 and especially in the early 1980s. The most important source of inflation risk in German stock returns is the risk associated with the inflation differential relative to the U.S. The sample mean of the absolute premium amounts to no less than 22 basis points on a monthly basis, or more than 2.5 percent per year. Since the mid 1980s, the premium for U.S. inflation risk has generally been negative and relatively stable. U.S. inflation risk carries a large and positive premium in the mid 1970s and is large and volatile in the first half of the 1980s. In this time period, the U.S. inflation risk component in expected returns on the MSCI Germany index is occasionally of the same order of magnitude as global market risk.

Figure 3 depicts the market risk, nominal exchange rate risk, and inflation risk components in the expected returns on equity indices in Japan and the U.S. (The corresponding graphs for the MSCI France, MSCI U.K., and MSCI World equity indices are available from the authors.) Table 4 provides summary statistics of the magnitude of the different risk premia. Both aggregate nominal exchange rate risk premia and aggregate inflation risk premia are substantial, in the full sample period as well as in the first and second half of the sample period. For France the full-sample average market risk premium is 125 basis points per month and the mean absolute nominal exchange rate and inflation risk premia amount to 56 and 57 basis points, respectively. The nominal exchange rate risk premium is always negative, while inflation risk generally entails a positive risk premium in French stock returns. There are considerable differences in the relative 
importance of currency and inflation risk among the other countries in the sample. For the U.K. in particular, nominal exchange rate risk and inflation risk represent very significant parts of the total risk premium. The average absolute risk inflation risk premium equals 35 basis points per month for U.K. equity. For Japan and the U.S., inflation risk premia are smaller, but nevertheless non-trivial (mean absolute values of, respectively, 27 and 22 basis points per month). The exchange rate and inflation risk premia are generally of opposite sign for France and the U.K., while they often reinforce each other for Japan and the U.S. Note that the graphs in Figure 3 do not provide insights into the magnitude and development of individual currency and inflation risk premia. As an example, the sample averages of absolute inflation risk premia incorporated in U.S. stock returns (in basis points) are equal to, respectively, 27 per month for French, 20 for Japanese, 12 for British, and 29 for U.S inflation.

\subsection{Conditional asset pricing model with nominal exchange rate and individual inflation risk}

Table 5 shows the test results of the model in equation (4). In this model, we drop the assumption that the inflation rate in the numeraire country is non-stochastic, which we used to arrive at the specification of the model in equation (2). In equation (4), expected asset returns are determined by their covariance with the global market factor, four nominal exchange rate factors, and five inflation rate factors. The likelihood-ratio test results are very similar to those reported in Table 3. For all ten risk factors considered in this model, we reject the hypothesis that their prices of risk are constant over time as well as the hypothesis that they are equal to zero. Hence, the main test results are similar when the inflation risk factors are not expressed in excess of the numeraire inflation rate and an additional risk factor associated with stochastic inflation in the numeraire country is added to the model. Consistent with the findings in section 5.2, unreported results show that the economic significance of inflation risk premia is substantial. Especially for France, 
Germany, and Japan, the contribution of inflation risk premia to expected stock returns is comparable in magnitude to the total nominal exchange rate risk premia.

\section{The termination of nominal exchange risk in the euro area}

This section analyzes whether asset returns still contain a risk premium for risk related to euro area inflation differentials after nominal exchange rates were frozen among euro area countries at the establishment of the EMU in 1999. While this obviously implies that nominal exchange rate risk between these countries does not carry a price, inflation differentials may still imply non-zero prices of real exchange rate risk. ${ }^{10}$ We present estimates and tests of the model incorporating nominal exchange rate and inflation risk depicted in equation (3) for asset returns in France, Germany, Japan, the U.K., and the U.S. over the period 1975:01-2003:12. As studying the euro area in isolation could lead to biases due to the fact that we would neglect non-EMU sources of currency risk, we also include other countries and currencies in the analysis. At the same time, we need to restrict the total number of countries analyzed, because the incorporation of more assets and risk factors hampers the estimation procedure considerably. Hence, our analysis focuses on the price of inflation risk related to inflation differentials between France and Germany. ${ }^{11}$ Unfortunately, estimating the model over the post-euro period is not feasible, because the number of parameters to be estimated requires a substantial time-series. However, estimating the model

\footnotetext{
${ }^{10}$ Several empirical studies indicate that substantial real exchange rate changes (i.e. inflation differentials) occur within a single currency zone. Parsley and Wei (1996) and Cecchetti, Mark, and Sonora (2002) report half-lifes of price discrepancies between different U.S. cities that amount to 1 to 4 years and around 9 years, respectively. Rogers (2001) and Lutz (2002) analyze price data for various European cities and find substantial deviations from the law of one price. Qin and Tan (2009) suggest that currency unions could reduce the level of inflation, but Angeloni and Ehrmann (2007) show that inflation differences among euro area countries are still prominent five years after the introduction of the euro. Koedijk, Tims, and van Dijk (2004) present evidence against the hypothesis of PPP for individual country pairs within the euro area.

${ }^{11}$ Unreported results show that similar findings are obtained when we estimate the model with data for other European countries (e.g., Italy or the Netherlands) instead of France. We bias our results against finding significant intra-EMU inflation risk after the introduction of the euro by choosing a country that is economically closely integrated with Germany. Additional results are available from the authors.
} 
over the full period 1975-2003 raises a challenge, as the nominal exchange rate of the French franc versus the German mark experiences a structural break in 1999. This structural break affects the estimation of the covariance matrix in particular, as the volatility of the concerning variable becomes zero by definition after 1998. We apply an adaptation of the methodology of De Santis and Gérard (1998) to deal with this issue. We provide a detailed description in Appendix A.

Table 6 presents the results of several specification tests of the model estimated over the period $1975-2003 .^{12}$ The world price of market risk is highly significant, although we no longer reject the hypothesis that this price of risk is constant over time. We find evidence of statistically significant prices of risk for all four nominal exchange rates in the sample. The evidence is strong for the exchange rate of the French franc versus the German mark, but slightly weaker for the other currencies in the sample. The tests reject a specification of the model in which the prices of nominal exchange rate risk are constant. Consistent with the results in the previous section, inflation risk factors carry significant prices of risk, both jointly and individually. We reject both the hypotheses that the prices of inflation risk are equal to zero and that the prices are constant over time at any conventional significance level. We are particularly interested in the development of the price of risk related to the inflation differential of France versus Germany as shown in Figure 4. The absolute level of the price of inflation risk in 1999-2003 does not appear to be notably lower than in the period before the introduction of the common currency (except for the high prices in the early 1980s). During the post-euro period the price of inflation risk remains substantial. The price of risk is positive in the first three years after 1999 and becomes negative in 2002 and 2003. Overall, these findings suggest that even when nominal exchange rates do not fluctuate, differences in inflation rates across countries may lead to non-zero risk premia.

\footnotetext{
12 The estimation results are very similar to those reported in Table 3, as the samples largely overlap. To conserve space, we do not include the parameter estimates of the model in the table. They are available from the authors.
} 


\section{Discussion}

Our results indicate that inflation risk is a distinct and significant source of systematic risk in international asset returns. In the framework of Adler and Dumas (1983), priced inflation risk arises because investors use part of their portfolio to hedge against domestic inflation risk. In other words, the price of inflation risk should be negative so that assets whose returns are high in times of high inflation earn lower expected returns. Cooper and Kaplanis (1994) investigate whether inflation hedging can explain the home bias puzzle and conclude that this explanation would require implausibly low levels of risk aversion. Our result that prices of inflation risk assume both negative and positive values over prolonged periods of time cannot be explained by the inflation hedging motive alone. But there may be other reasons why inflation carries a price of risk. Ferson and Harvey (1991) argue that "unanticipated inflation could be a source of economic risk if inflation has real effects, in the sense that inflation is correlated with aggregate marginal utility." Geske and Roll (1983) point at the relation with real activity and monetary policy. French, Ruback, and Schwert (1983) highlight the role of nominal contracting in firms. We invite future studies to address the underlying economic forces driving inflation risk.

Why are the magnitudes of inflation risk premia comparable to those of nominal exchange rate risk premia, while the time-series volatility of inflation differentials is notably smaller than nominal exchange rate volatility? First, inflation rates are much more persistent than nominal exchange rate returns. Hence, minor shocks to inflation rates in the short run can have large consequences over long horizons. Second, hedging inflation risk is considerably more difficult than hedging currency risk. Hedging currency risk is easy and cheap due to the availability of exchange-traded financial products on generally very liquid markets. The most straightforward way to hedge inflation risk is through index-linked bonds. U.K. index linked gilts were first 
issued in 1981 and U.S. Treasury Inflation protected Securities (TIPS) were introduced in 1997. However, Bar and Campbell (1997) and Evans (1998) emphasize that U.K. index-linked bonds are an imperfect hedge against inflation risk due to partial indexation. In addition, both U.K. and U.S. index-linked bonds suffered from illiquidity, especially in the early years after their introduction. Shen and Corning (2001) point out that the yield difference between nominal and index-linked bonds is not only driven by inflation expectations, but also by inflation risk and liquidity risk. Based on an analysis of 10-year TIPS over 1997-2001, they conclude that the yield difference is a "poor measure of market expected inflation" - in part because of the low liquidity. Furthermore, index-linked bonds are only available in a small number of countries and were not available during most of our sample period (with the exception of index-linked bonds in the U.K.). Similar issues hamper the effectiveness of other financial instruments - such as zerocoupon inflation-indexed swaps (see, e.g., Hinnerich, 2008) - as a hedge against inflation.

Nevertheless, the question whether an improvement in the instruments available for hedging inflation risk has an impact on the price of inflation risk implied by international asset returns is interesting and important. Shen and Corning (2001) suggest that yield difference between nominal and index-linked bonds in the U.S. may become a more powerful predictor of inflation rates as the liquidity of the index-linked bond market improves. To examine this hypothesis, we collect data on "Primary Dealer Transactions in U.S. Government Securities Treasury Inflation Index Securities" from the website of the Federal Reserve Bank of New York.

Over the six years during our sample period for which we have data on the trading volume in TIPS, we observe a remarkable increase in the liquidity of the index-linked bond market as well as a decline in the price of U.S. inflation risk (using the model estimates with individual prices of inflation risk for Germany, Japan, the U.K., and the U.S. over the period 1975-2003, as discussed in section 4). Over 1998-2000, the average daily trading volume in TIPS was around 
\$1b. and the average price of U.S. inflation risk was 5.333. Over 2001-2003, the average daily TIPS trading volume was over $\$ 2.5 \mathrm{~b}$. and the average price of U.S. inflation risk was 2.558 .

In both of these periods, assets that have a positive exposure to U.S. inflation risk thus have higher expected returns, which suggests that inflation risk is not priced because of the Adler and Dumas (1983) hedging argument, but because investors view inflation risk as a risk factor for which they want to be compensated. However, the compensation per unit of this type of risk over 2001-2003 is less than half the compensation over 1998-2000. It is possible that the decrease in the compensation for exposure to U.S. inflation risk demanded by investors is driven by enhanced possibilities to hedge this type of risk.

The simple correlation between monthly TIPS trading volume and the price of U.S. inflation risk over $1998-2003$ is -0.72 , with a $t$-statistic of -8.86 . Of course, these numbers are based on a limited amount of data. And we should interpret correlations between variables that exhibit trends with caution. But it is interesting to see that the reduction in the price of U.S. inflation risk at the end of the sample period takes place in a way that is consistent with an explanation related to the increased value of index-linked bonds as an inflation hedging instrument. We leave a thorough investigation of these and other issues for future research.

\section{Conclusions}

This paper analyzes whether inflation risk is priced in international asset returns. We test two assumptions commonly made in the international asset pricing literature. First, the Solnik-Sercu ICAPM and the empirical tests of the ICAPM by Dumas and Solnik (1995) and De Santis and Gérard (1998) assume that domestic inflation rates expressed in local currency are non-stochastic and hence inflation risk is not priced. Second, the ICAPM does not allow for a specification in which inflation risk and nominal exchange rate risk are independent sources of risk. 
Our empirical evidence suggests that inflation risk premia are an important and distinct component of expected international stock returns and imply a rejection of the ICAPM. Using the methodology of De Santis and Gérard (1997, 1998), we estimate and test an international pricing model including inflation risk factors using asset returns from Germany, France, Japan, the U.K., and the U.S. from 1975 up to 2003. We present evidence of significant time-varying prices of inflation risk, even within the euro area after the termination of nominal exchange rate fluctuations in 1999. The impact of inflation risk on asset returns is substantial from an economic point of view. Inflation risk premia are generally of the same order of magnitude as nominal exchange rate risk premia. Even though variances of and covariances of asset returns with the inflation risk factors are low compared with the nominal exchange rate risk factors, the prices of inflation risk are much higher than the prices of nominal exchange rate risk. We explain these findings by the fact that inflation risk is much harder to hedge than exchange rate risk. 


\section{Appendix A. Empirical methodology for section 6: The termination of nominal exchange rate risk in the euro area}

This appendix contains a detailed description of the methodology used to estimate the conditional model in section 6 of this paper. Because this analysis covers both the pre-euro and the post-euro period and we include both France and Germany, our estimation procedure has to take into account that the nominal exchange rate between these countries was frozen after they adopted the euro. This implies a structural break in the nominal exchange rate series, as a result of which we cannot use the same specification for this risk factor before and after 1999. In general, the structural break leads to two versions of equation (3):

$$
\begin{aligned}
E\left[r_{i t} \mid \Omega_{t-1}\right] & =\delta_{m, t-1} \operatorname{cov}\left[r_{i t}, r_{m t} \mid \Omega_{t-1}\right]+\sum_{l=1}^{L} \delta_{l, t-1} \operatorname{cov}\left[r_{i t}, s_{l t} \mid \Omega_{t-1}\right] \\
& +\sum_{l=1}^{L} \gamma_{l, t-1} \operatorname{cov}\left[r_{i t},\left(\pi_{l t}-\pi_{0 t}\right) \mid \Omega_{t-1}\right] \quad i=1, \ldots, M \quad t<\text { Jan } 1999
\end{aligned}
$$

Equation (A1) is exactly the same as equation (3) and holds as long as the nominal exchange rates

are not frozen (the euro was adopted on January 1, 1999). Suppose, without loss of generality, that the euro area exchange rates are the last $N$ excess returns in $r_{i t}$. We can then express the model for the second part of the sample period as follows:

$$
\begin{aligned}
& E\left[r_{i t}^{\prime} \mid \Omega_{t-1}\right]=\delta_{m, t-1} \operatorname{cov}\left[r_{i t}^{\prime}, r_{m t} \mid \Omega_{t-1}\right]+\sum_{l=1}^{L-N} \delta_{l, t-1} \operatorname{cov}\left[r_{i t}^{\prime}, S_{l t} \mid \Omega_{t-1}\right] \\
&+\sum_{l=1}^{L} \gamma_{l, t-1} \operatorname{cov}\left[r_{i t}^{\prime},\left(\pi_{l t}-\pi_{0 t}\right) \mid \Omega_{t-1}\right] \quad i=1, \ldots, M-N \quad t \geq \text { Jan } 1999
\end{aligned}
$$

where $N$ is the number of frozen nominal exchange rates and $r^{\prime}{ }_{i t}$ denotes the vector of $(M-N)$ excess returns. In our empirical application, we estimate all parameters in the mean equation of (A2) using the full sample period, while we estimate the parameters concerning the frozen exchange rates using data until December 1998 only. 
The structural break also has consequences for the estimation of the conditional covariance matrix. Because the number of elements in the return vector decreases as of January 1999, the size of covariance matrix is reduced. This means that after 1999 we only use the upper $(M-N) \times(M-N)$ part of the original covariance matrix. The same holds for the parameters, as only the first $(M-N)$ values of the vectors $a$ and $b$ apply after 1999 . The new covariance matrix equation is as follows (with new notation for all symbols to denote the difference with equation (8)):

$$
\begin{aligned}
& H_{t}^{\prime}{ }_{t}=H^{\prime}{ }_{0} *\left(l \imath^{\prime}-c c^{\prime}-d d^{\prime}\right)+c c^{\prime} * \eta_{t-1} \eta_{t-1}^{\prime}+d d^{\prime} * H^{\prime}{ }_{t-1} \\
& c=a[1: M-N] \\
& d=b[1: M-N] \\
& \eta_{t-1}=\varepsilon_{t-1}[1: M-N]
\end{aligned}
$$

where $H^{\prime}{ }_{t}$ is the $(M-N) \times(M-N)$ covariance matrix at time $t$ and $H^{\prime}{ }_{0}$ is the $(M-N) \times(M-N)$ unconditional covariance matrix. We set the unconditional covariance matrix $H_{0}^{\prime}$ equal to the sample covariance matrix of the returns over the full sample, while the $H_{0}$ of equation (8) is based on the sample until December 1998. This is necessary to provide a plausible estimate of the covariances with the nominal exchange rates that disappear after January 1999. Although we reckon that this approach is the best solution to the structural break problem within this framework, our results should be interpreted with care. 


\section{References}

Adler, M., Dumas, B., 1983. International portfolio choice and corporation finance: A synthesis. Journal of Finance 38, 925-984.

Ang, A., Bekaert, G., 2008. The term structure of real rates and expected inflation. Journal of Finance 63, 797-849.

Angeloni, I., Ehrmann, M., 2007. Euro area inflation differentials. B.E. Journal of Macroeconomics, 7, Issue 1, Article 24.

Barr, D.G., Campbell, J.Y., 1997. Inflation, real interest rates, and the bond market: A study of UK nominal and index-linked government bond prices. Journal of Monetary Economics 39, 361-383.

Bekaert, G., Wu, G., 2000. Asymmetric volatility and risk in equity markets. Review of Financial Studies 13, 1-42.

Bodie, Z., 1976. Common stocks as a hedge against inflation. Journal of Finance 31, 459-470.

Bollerslev, T., Wooldridge, J., 1992. Quasi-maximum likelihood estimation and inference in dynamic models with time-varying covariances. Econometric Reviews 11, 143-172.

Brennan, M.J., Xia, Y., 2002. Dynamic asset allocation under inflation. Journal of Finance 57, 1201-1238.

Buraschi, A., Jiltsov, A., 2005. Inflation risk premia and the expectations hypothesis. Journal of Financial Economics 75, 429-490.

Campbell, J.Y., 1993. Intertemporal asset pricing without consumption data. American Economic Review 83, 487-512.

Campbell, J.Y., Chan, Y.L., Viceira, L.M., 2003. A multivariate model of strategic asset allocation. Journal of Financial Economics 67, 41-80.

Campbell, J.Y., Viceira, L.M., 2001. Who should buy long-term bonds? American Economic Review 91, 99-127.

Carrieri, F., 2001. The effects of liberalization on market and currency risk in the European Union. European Financial Management 7, 259-290.

Carrieri, F., Errunza, V., Majerbi, B., 2006. Does emerging market exchange risk affect global equity prices? Journal of Financial and Quantitative Analysis 41, 511-540.

Cecchetti, S.G., Mark, N.C., Sonora, R.J., 2002. Price index convergence among United States cities. International Economic Review 43, 1081-1099.

Chaieb, I., Errunza, V., 2007. International asset pricing under segmentation and PPP deviations. Journal of Financial Economics 86, 543-578.

Chang, J., Errunza, V., Hogan, K., Hung, M., 2005. An intertemporal international asset pricing model: Theory and empirical evidence. European Financial Management 11, 173-194.

Chen, N.-F., Roll, R., Ross, S.A., 1986. Economic forces and the stock market. Journal of Business 59, 383-403.

Cooper, I., Kaplanis, E., 1994. Home bias in equity portfolios, inflation hedging, and international capital market equilibrium. Review of Financial Studies 7, 45-60. 
De Santis, G., Gérard, B., 1997. International asset pricing and portfolio diversification with time-varying risk. Journal of Finance 52, 1881-1912.

De Santis, G., Gérard, B., 1998. How big is the premium for currency risk? Journal of Financial Economics 49, 375-412.

De Santis, G., Gérard, B., Hillion, P., 2003. The relevance of currency risk in the EMU. Journal Economics and Business 55, 427-462.

Dumas, B., 1994. Partial equilibrium versus general equilibrium models of the international capital market. In van der Ploeg, F. (Ed.), Handbook of International Macroeconomics, Vol. 9, Blackwell, 301-347.

Dumas, B., Solnik, B., 1995. The world price of exchange rate risk. Journal of Finance 50, 445479.

Elton, E., Gruber, M., Rentzler, J., 1983. The arbitrage pricing model and returns on assets under uncertain inflation. Journal of Finance 38, 525-536.

Engle, R.F., Ng, V.K., 1993. Measuring and testing the impact of news on volatility. Journal of Finance 48, 1749-1778.

Evans, M.D.D., 1998. Real rates, expected inflation, and inflation risk premia. Journal of Finance 53, 187-218.

Fama, E.F., Schwert, G.W., 1977. Asset returns and inflation. Journal of Financial Economics 5, 115-146.

Ferson, W.E., Harvey, C.R., 1991. The variation of economic risk premiums. Journal of Political Economy 99, 385-415.

Ferson, W.E., Harvey, C.R., 1993. The risk and predictability of international equity returns. Review of Financial Studies 6, 527-566.

Ferson, W.E., Harvey, C.R., 1994. Sources of risk and expected returns in global equity markets. Journal of Banking and Finance 18, 775-803.

French, K.R., Ruback, R.S., Schwert, G.W., 1983. Effects of nominal contracting on stock returns. Journal of Political Economy 91, 70-96.

Geske, R., Roll, R., 1983. The fiscal and monetary linkage between stock returns and inflation. Journal of Finance 38, 1-33.

Glosten, L.R., Jagannathan, R., Runkle, D.E., 1993. Relationship between the expected value and the volatility of the nominal excess return on stocks. Journal of Finance 48, 1779-1801.

Grauer, F.L.A., Litzenberger, R.H., Stehle, R.E., 1976. Sharing rules and equilibrium in an international capital market under uncertainty. Journal of Financial Economics 3, 233256.

Gultekin, M.N., Gultekin, N.B., Penati, A., 1989. Capital controls and international capital market segmentation: The evidence from the Japanese and American stock markets. Journal of Finance 44, 849-869.

Harvey, C.R., 1991. The world price of covariance risk. Journal of Finance 46, 111-157. 
Hinnerich, M., 2008. Inflation-indexed swaps and swaptions. Journal of Banking and Finance 32, 2293-2306.

Joyce, M.A.S., Lildholdt, P., Sorensen, S., 2009. Extracting inflation expectations and inflation risk premia from the term structure: A joint model of the UK nominal and real yield curves. Journal of Banking and Finance, forthcoming.

Koedijk, C.G., Tims, B., van Dijk, M.A., 2004. Purchasing power parity and the euro area. Journal of International Money and Finance 23, 1081-1107.

Kroner, K.F., Ng, V.K., 1998. Modeling the time varying comovement of asset returns. Review of Financial Studies 11, 817-844.

Lutz, M., 2002. Price convergence under EMU? First estimates. Working paper, University of St. Gallen.

Mazzotta, S., 2008. How important is asymmetric covariance for the risk premium of international assets? Journal of Banking and Finance 32, 1636-1647.

$\mathrm{Ng}$, D.T., 2004. The international CAPM when expected returns are time-varying. Journal of International Money and Finance 23, 189-230.

Parsley, D.C., Wei, S.-J., 1996. Convergence to the law of one price without trade barriers or currency fluctuations. Quarterly Journal of Economics 111, 1211-1236.

Qin, D., Tan, T., 2009. How much intraregional exchange rate variability could a currency union remove? The case of ASEAN+3. Journal of Banking and Finance 33, 1793-1803.

Rogers, J.H, 2001. Price level convergence, relative prices, and inflation in Europe. International Finance Discussion Papers, 699, Board of Governors of the Federal Reserve System.

Rogoff, K., 1996. The purchasing power parity puzzle. Journal of Economic Literature 34, 647668.

Sercu, P., 1980. A generalization of the international asset pricing model. Revue de l'Association Française de Finance 1, 91-135.

Shen, P., Corning, J., 2001. Can TIPS help identify long-term inflation expectations? Federal Reserve Bank of Kansas City Economic Review, Fourth Quarter, 61-87.

Solnik, B., 1974. An equilibrium model of the international capital market. Journal of Economic Theory, 8, 500-524.

Stulz, R.M., 1981. A model of international asset pricing. Journal of Financial Economics 9, 383406.

Stulz, R.M., 1986. Asset pricing and expected inflation. Journal of Finance 41, 209-223.

Stulz, R.M., 1995. International portfolio choice and asset pricing: An integrative survey. In Jarrow, R.A., Maksimovic, V., Ziemba, W.T. (Eds.), Handbooks in Operations Research and Management Science, Vol. 9. North-Holland: Amsterdam, 201-223.

Vassalou, M., 2000. Exchange rate and foreign inflation risk premiums in global equity returns. Journal of International Money and Finance 19, 433-470. 
Table 1

\section{Summary statistics (1975-1998)}

This table reports summary statistics for the asset excess returns expressed in German marks over the period 1975:01-1998:12. Equity indices are from Morgan Stanley Capital International (MSCI). We construct real exchange rates versus the German mark from nominal exchange rates and CPI indices obtained from International Financial Statistics (IFS). We use the one-month euro-mark deposit quoted in London as the conditionally risk-free asset. We express all returns as a percentage per month. J-B is the Jarque-Bera test statistic for normality. $\mathrm{Q}_{12}$ denotes the $p$-value of the Ljung-Box test statistic of order $12 . *$, **, *** denote significance at the $10 \%, 5 \%$, and $1 \%$ significance levels, respectively.

\begin{tabular}{|c|c|c|c|c|c|c|c|}
\hline & Mean & Median & St.Dev. & Skewness & Kurtosis & $\mathbf{J}-\mathbf{B}$ & $\mathbf{Q}_{12}$ \\
\hline \multicolumn{8}{|c|}{ PANEL A: SUMMARY STATISTICS OF STOCK RETURNS AND REAL EXCHANGE RATE RETURNS } \\
\hline MSCI Germany & 0.698 & 0.803 & 5.380 & -0.507 & 5.130 & $66.8 * * *$ & 15.4 \\
\hline MSCI France & 0.874 & 0.918 & 6.459 & 0.007 & 4.177 & $16.6^{* * *}$ & 10.1 \\
\hline MSCI Japan & 0.593 & 0.744 & 6.519 & 0.137 & 3.928 & $11.2 * * *$ & 10.0 \\
\hline MSCI U.K. & 1.169 & 1.519 & 6.957 & 1.124 & 12.861 & $1227.5 * * *$ & 14.7 \\
\hline MSCI U.S. & 0.854 & 1.028 & 5.429 & -0.533 & 5.051 & $64.1 * * *$ & 9.3 \\
\hline MSCI World & 0.710 & 0.894 & 4.570 & -0.646 & 5.070 & $71.5 * * *$ & $19.0^{*}$ \\
\hline Real exchange rate France & -0.002 & -0.094 & 1.178 & 1.247 & 9.654 & $606.0 * * *$ & 13.2 \\
\hline Real exchange rate Japan & -0.149 & 0.147 & 3.122 & -0.409 & 3.857 & $16.2 * * *$ & 15.5 \\
\hline Real exchange rate U.K. & -0.073 & -0.082 & 2.739 & 0.292 & 4.337 & $25.5^{* * * *}$ & 12.2 \\
\hline Real exchange rate U.S. & 0.019 & 0.072 & 3.286 & -0.084 & 3.968 & $11.6^{* * *}$ & 12.6 \\
\hline \multicolumn{8}{|c|}{ PANEL B: SUMMARY STATISTICS OF INSTRUMENTS } \\
\hline Dividend yield MSCI World & -0.349 & -0.318 & 0.217 & -1.104 & 4.759 & $95.6 * * *$ & $2095.2 * * *$ \\
\hline U.S. default premium & 1.152 & 1.080 & 0.480 & 0.940 & 3.313 & $43.6^{* * *}$ & $2254.7 * * *$ \\
\hline Change in U.S. term premium & 0.006 & 0.000 & 0.679 & 1.708 & 21.283 & $4151.0 * * *$ & $84.7 * * *$ \\
\hline
\end{tabular}


Table 1 - continued

Summary statistics (1975-1998)

This table reports summary statistics for the excess returns over the period 1975:01-1998:12. J-B is the Jarque-Bera test statistic for normality. Q ${ }_{12}$ denotes the Ljung-Box test statistic of order $12 . * * *, * * *$ denote significance at the $10 \%, 5 \%$, and $1 \%$ significance levels, respectively.

\begin{tabular}{|c|c|c|c|c|c|c|c|}
\hline & Mean & Median & St.Dev. & Skewness & Kurtosis & $\mathbf{J}-\mathbf{B}$ & $\mathbf{Q}_{12}$ \\
\hline \multicolumn{8}{|c|}{ PANEL C: SUMMARY STATISTICS OF NOMINAL EXCHANGE RATES AND INFLATION DIFFERENTIALS } \\
\hline Nominal exchange rate France & 0.215 & 0.083 & 1.158 & 1.845 & 10.741 & $882.4 * * *$ & $25.1 * *$ \\
\hline Nominal exchange rate Japan & -0.158 & 0.030 & 3.067 & -0.449 & 3.821 & $17.7 * * *$ & 15.1 \\
\hline Nominal exchange rate U.K. & 0.282 & 0.191 & 2.677 & 0.394 & 4.505 & $34.6 * * *$ & 11.0 \\
\hline Nominal exchange rate U.S. & 0.181 & 0.244 & 3.291 & -0.041 & 3.941 & $10.7 * * *$ & 11.2 \\
\hline Inflation differential France & -0.216 & -0.194 & 0.414 & -0.260 & 4.847 & $44.1 * * *$ & $404.5 * * *$ \\
\hline Inflation differential Japan & 0.009 & 0.008 & 0.633 & -0.544 & 4.027 & $26.9 * * *$ & $167.5 * * *$ \\
\hline Inflation differential U.K. & -0.353 & -0.277 & 0.679 & -1.118 & 9.135 & $511.7 * * *$ & $197.3 * * *$ \\
\hline Inflation differential U.S. & -0.161 & -0.156 & 0.371 & -0.209 & 6.462 & $146.0 * * *$ & $161.4 * * *$ \\
\hline
\end{tabular}


Table 1 - continued

Summary statistics (1975-1998)

This table reports unconditional correlations of the (excess) returns over the period 1975:01-1998:12.

\begin{tabular}{|c|c|c|c|c|c|c|c|c|c|c|}
\hline & $\begin{array}{c}\text { MSCI } \\
\text { Germany } \\
\end{array}$ & $\begin{array}{c}\text { MSCI } \\
\text { France }\end{array}$ & $\begin{array}{l}\text { MSCI } \\
\text { Japan } \\
\end{array}$ & $\begin{array}{c}\text { MSCI } \\
\text { U.K. }\end{array}$ & $\begin{array}{c}\text { MSCI } \\
\text { U.S. } \\
\end{array}$ & $\begin{array}{c}\text { r.e.r. } \\
\text { France }\end{array}$ & $\begin{array}{c}\text { r.e.r. } \\
\text { Japan }\end{array}$ & $\begin{array}{l}\text { r.e.r. } \\
\text { U.K. }\end{array}$ & $\begin{array}{l}\text { r.e.r. } \\
\text { U.S. }\end{array}$ & $\begin{array}{l}\text { MSCI } \\
\text { World } \\
\end{array}$ \\
\hline \multicolumn{11}{|c|}{ PANEL D: UNCONDITIONAL CORRELATIONS BETWEEN STOCK RETURNS AND REAL EXCHANGE RATE RETURNS } \\
\hline MSCI Germany & 1 & 0.550 & 0.283 & 0.412 & 0.414 & 0.006 & -0.022 & -0.081 & -0.131 & 0.529 \\
\hline MSCI France & & 1 & 0.362 & 0.520 & 0.467 & -0.281 & -0.142 & -0.153 & -0.148 & 0.597 \\
\hline MSCI Japan & & & 1 & 0.352 & 0.343 & -0.092 & -0.555 & -0.206 & -0.194 & 0.686 \\
\hline MSCI U.K. & & & & 1 & 0.535 & -0.239 & -0.179 & -0.471 & -0.233 & 0.674 \\
\hline MSCI U.S. & & & & & 1 & -0.163 & -0.220 & -0.258 & -0.609 & 0.880 \\
\hline Real exchange rate France & & & & & & 1 & 0.229 & 0.314 & 0.256 & -0.170 \\
\hline Real exchange rate Japan & & & & & & & 1 & 0.263 & 0.401 & -0.365 \\
\hline Real exchange rate U.K. & & & & & & & & 1 & 0.401 & -0.343 \\
\hline Real exchange rate U.S. & & & & & & & & & 1 & -0.494 \\
\hline \multirow[t]{2}{*}{ MSCI World } & & & & & & & & & & 1 \\
\hline & $\begin{array}{c}\text { n.e.r. } \\
\text { France }\end{array}$ & $\begin{array}{l}\text { n.e.r. } \\
\text { Japan }\end{array}$ & $\begin{array}{c}\text { n.e.r. } \\
\text { U.K. }\end{array}$ & $\begin{array}{c}\text { n.e.r. } \\
\text { U.S. }\end{array}$ & $\begin{array}{c}\text { infl. diff. } \\
\text { Fra }\end{array}$ & $\begin{array}{c}\text { infl. diff. } \\
\text { U.K. }\end{array}$ & $\begin{array}{c}\text { infl. diff. } \\
\text { Jap }\end{array}$ & $\begin{array}{c}\text { infl. diff. } \\
\text { U.S. }\end{array}$ & & \\
\hline \multicolumn{11}{|c|}{ PANEL E: UNCONDITIONAL CORRELATIONS BETWEEN STOCK RETURNS, NOMINAL EXCHANGE RATE RETURNS, AND INFLATION DIFFERENTIALS } \\
\hline MSCI Germany & -0.008 & -0.028 & -0.092 & -0.142 & 0.040 & 0.029 & 0.032 & 0.096 & & \\
\hline MSCI France & -0.281 & -0.145 & -0.141 & -0.150 & -0.017 & 0.000 & -0.064 & 0.015 & & \\
\hline MSCI Japan & -0.090 & -0.566 & -0.213 & -0.204 & -0.011 & 0.007 & 0.007 & 0.088 & & \\
\hline MSCI U.K. & -0.252 & -0.183 & -0.461 & -0.244 & 0.021 & 0.002 & -0.090 & 0.101 & & \\
\hline MSCI U.S. & -0.189 & -0.239 & -0.275 & -0.623 & 0.061 & 0.068 & 0.037 & 0.121 & & \\
\hline MSCI World & -0.190 & -0.384 & -0.355 & -0.509 & 0.044 & 0.053 & 0.011 & 0.138 & & \\
\hline Nominal exchange rate France & & & & & -0.121 & -0.030 & 0.019 & 0.000 & & \\
\hline Nominal exchange rate Japan & & & & & 0.023 & -0.018 & -0.032 & -0.011 & & \\
\hline Nominal exchange rate U.K. & & & & & -0.042 & -0.053 & -0.019 & 0.046 & & \\
\hline Nominal exchange rate U.S. & & & & & -0.036 & -0.087 & -0.093 & -0.051 & & \\
\hline
\end{tabular}




\section{Table 2}

\section{The conditional ICAPM with time-varying prices of market and real exchange rate risk (1975-1998)}

This table depicts quasi-maximum likelihood estimation results of the conditional ICAPM in equation (2) over the period 1975:01-1998:12. Equity indices are from Morgan Stanley Capital International (MSCI). We construct real exchange rates versus the German mark from nominal exchange rates and CPI indices obtained from International Financial Statistics (IFS). We use the one-month euro-mark deposit quoted in London as the conditionally risk-free asset. Each mean equation relates the asset excess return $r_{i t}$ to the covariance with global stock returns $\operatorname{cov}\left(r_{i t}, r_{m t} \mid \Omega_{t-1}\right)$ and the covariance with real exchange rate returns $\operatorname{cov}\left(r_{i t}, q_{l t} \mid \Omega_{t-1}\right)$. The prices of risk are functions of instruments in $Z_{t-1}$, which proxy for the information set $\Omega_{t-1}$ that investors use in choosing their portfolios. The instruments include a constant, the dividend yield on the MSCI world index in excess of the one-month euro-dollar rate (WorldDY), the default premium in the U.S. (USDP), and the change in the U.S. term premium ( $\Delta$ USTP).

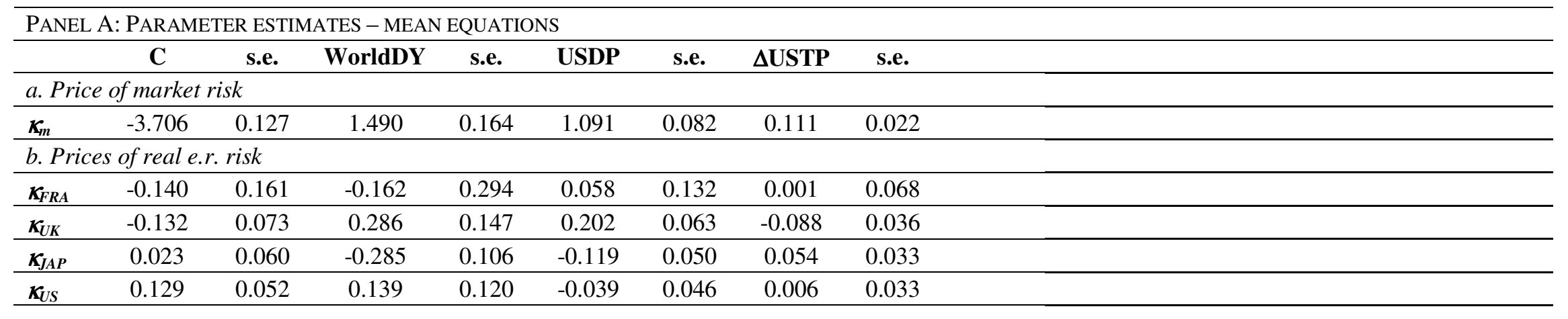

\begin{tabular}{|c|c|c|c|c|c|c|c|c|c|c|}
\hline \multicolumn{11}{|c|}{ PANEL B: PARAMETER ESTIMATES - COVARIANCE PROCESS } \\
\hline & $\begin{array}{c}\text { MSCI } \\
\text { Ger }\end{array}$ & $\begin{array}{c}\text { MSCI } \\
\text { Fra }\end{array}$ & $\begin{array}{c}\text { MSCI } \\
\text { U.K. }\end{array}$ & $\begin{array}{c}\text { MSCI } \\
\text { Jap }\end{array}$ & $\begin{array}{c}\text { MSCI } \\
\text { U.S. }\end{array}$ & $\begin{array}{c}\text { r.e.r. } \\
\text { Fra }\end{array}$ & $\begin{array}{l}\text { r.e.r. } \\
\text { U.K. }\end{array}$ & $\begin{array}{c}\text { r.e.r. } \\
\text { Jap }\end{array}$ & $\begin{array}{l}\text { r.e.r. } \\
\text { U.S. }\end{array}$ & $\begin{array}{l}\text { MSCI } \\
\text { World }\end{array}$ \\
\hline $\mathbf{a}$ & 0.186 & 0.172 & 0.233 & 0.213 & 0.232 & 0.145 & 0.182 & 0.208 & 0.193 & 0.206 \\
\hline s.e. & 0.032 & 0.028 & 0.020 & 0.021 & 0.021 & 0.023 & 0.072 & 0.041 & 0.038 & 0.017 \\
\hline b & 0.965 & 0.981 & 0.960 & 0.957 & 0.950 & 0.988 & 0.822 & 0.926 & 0.932 & 0.958 \\
\hline s.e. & 0.014 & 0.009 & 0.008 & 0.010 & 0.010 & 0.007 & 0.089 & 0.025 & 0.028 & 0.008 \\
\hline
\end{tabular}


Table 2 - continued

The conditional ICAPM with time-varying prices of market and real exchange rate risk (1975-1998)

Panel $\mathrm{C}$ of this table depicts the results of a number of specification tests of the conditional ICAPM in equation (2) over the period 1975:01-1998:12. *, **, *** denote significance at the $10 \%, 5 \%$, and $1 \%$ significance levels, respectively.

\begin{tabular}{|c|c|c|c|c|}
\hline \multicolumn{5}{|l|}{ PANEL C: SPECIFICATION TESTS } \\
\hline Hypothesis & LR-test & df & $p$-value & \\
\hline$H_{0}:$ The price of market risk is constant & 7.579 & 3 & 0.056 & $*$ \\
\hline $\mathrm{H}_{0}:$ The price of market risk is equal to zero & 19.602 & 4 & 0.001 & $* * *$ \\
\hline $\mathrm{H}_{0}$ : The price of real exchange rate risk is constant & 24.818 & 12 & 0.016 & $* *$ \\
\hline Real exchange rate France & 1.072 & 3 & 0.784 & \\
\hline Real exchange rate U.K. & 13.757 & 3 & 0.003 & $* * *$ \\
\hline Real exchange rate Japan & 10.472 & 3 & 0.015 & $* *$ \\
\hline Real exchange rate U.S. & 3.761 & 3 & 0.289 & \\
\hline $\mathrm{H}_{0}$ : The price of real exchange rate risk is equal to zero & 27.049 & 16 & 0.041 & $* *$ \\
\hline Real exchange rate France & 1.073 & 4 & 0.899 & \\
\hline Real exchange rate U.K. & 13.762 & 4 & 0.008 & $* * *$ \\
\hline Real exchange rate Japan & 10.778 & 4 & 0.029 & $* *$ \\
\hline Real exchange rate U.S. & 5.973 & 4 & 0.201 & \\
\hline
\end{tabular}




\section{Table 3}

\section{The conditional model with time-varying prices of market, nominal exchange rate, and inflation risk (1975-1998)}

This table depicts quasi-maximum likelihood estimation results of the conditional model in equation (3) over the period 1975:01-1998:12. Equity indices are from Morgan Stanley Capital International (MSCI). We construct real exchange rates versus the German mark from nominal exchange rates and CPI indices obtained from International Financial Statistics (IFS). We use the one-month euro-mark deposit quoted in London as the conditionally risk-free asset. Each mean equation relates the asset excess return $r_{i t}$ to the covariance with global stock returns $\operatorname{cov}\left(r_{i t}, r_{m t} \mid \Omega_{t-1}\right)$, the covariance with nominal exchange rate returns $\operatorname{cov}\left(r_{i t}, s_{l t} \mid \Omega_{t-1}\right)$, and the covariance with inflation rates in excess of the numeraire inflation $\operatorname{cov}\left(r_{i t}, \pi_{l t}-\pi_{0 t} \mid \Omega_{t-1}\right)$. The prices of risk are functions of instruments in $Z_{t-1}$, which proxy for the information set $\Omega_{t-1}$ that investors use in choosing their portfolios. The instruments include a constant, the dividend yield on the MSCI world index in excess of the one-month euro-dollar rate (WorldDY), the default premium in the U.S. (USDP), and the change in the U.S. term premium ( $\Delta \mathrm{USTP})$.

\begin{tabular}{|c|c|c|c|c|c|c|c|c|}
\hline \multicolumn{9}{|c|}{ PANEL A: PARAMETER ESTIMATES - MEAN EQUATIONS } \\
\hline & $\mathbf{C}$ & s.e. & WorldDY & s.e. & USDP & s.e. & $\Delta \mathbf{U S T P}$ & s.e. \\
\hline \multicolumn{9}{|c|}{ a. Price of market risk } \\
\hline$\kappa_{m}$ & -3.150 & 0.105 & 1.072 & 0.162 & 0.747 & 0.072 & 0.091 & 0.020 \\
\hline \multicolumn{9}{|c|}{ b. Prices of nominal e.r. risk } \\
\hline$\lambda_{F R A}$ & -0.125 & 0.116 & -0.136 & 0.277 & 0.201 & 0.124 & 0.015 & 0.083 \\
\hline$\lambda_{U K}$ & -0.083 & 0.069 & 0.232 & 0.150 & 0.200 & 0.060 & -0.076 & 0.038 \\
\hline$\lambda_{J A P}$ & 0.017 & 0.055 & -0.241 & 0.117 & -0.106 & 0.047 & 0.068 & 0.036 \\
\hline$\lambda_{U S}$ & 0.161 & 0.048 & 0.113 & 0.121 & -0.098 & 0.042 & -0.021 & 0.037 \\
\hline \multicolumn{9}{|c|}{ c. Prices of inflation risk } \\
\hline$\mu_{F R A}$ & 3.912 & 0.610 & -0.150 & 1.224 & -4.081 & 0.645 & -0.358 & 0.400 \\
\hline$\mu_{U K}$ & -0.825 & 0.243 & 0.035 & 0.594 & 0.131 & 0.291 & -0.364 & 0.212 \\
\hline$\mu_{J A P}$ & 0.315 & 0.350 & -0.494 & 0.607 & 0.307 & 0.335 & -0.245 & 0.138 \\
\hline$\mu_{U S}$ & -3.226 & 0.633 & 3.891 & 1.361 & 3.338 & 0.647 & 0.911 & 0.312 \\
\hline
\end{tabular}


Table 3 - continued

The conditional model with time-varying prices of market, nominal exchange rate, and inflation risk (1975-1998)

Panel B of this table depicts quasi-maximum likelihood estimation results of the conditional model in equation (3) over the period 1975:01-1998:12. Panel C of this table depicts the results of a number of specification tests of the conditional model with time-varying prices of risk over the period 1975:01-1998:12. *,**, *** denote significance at the $10 \%, 5 \%$, and $1 \%$ significance levels, respectively.

\begin{tabular}{|c|c|c|c|c|c|c|c|c|c|c|c|c|c|c|}
\hline \multicolumn{15}{|c|}{ PANEL B: PARAMETER ESTIMATES - COVARIANCE PROCESS } \\
\hline & $\begin{array}{c}\text { MSCI } \\
\text { Ger }\end{array}$ & $\begin{array}{c}\text { MSCI } \\
\text { Fra }\end{array}$ & $\begin{array}{c}\text { MSCI } \\
\text { U.K. }\end{array}$ & $\begin{array}{c}\text { MSCI } \\
\text { Jap }\end{array}$ & $\begin{array}{c}\text { MSCI } \\
\text { U.S. }\end{array}$ & $\begin{array}{c}\text { n.e.r. } \\
\text { Fra }\end{array}$ & $\begin{array}{c}\text { n.e.r. } \\
\text { U.K. }\end{array}$ & $\begin{array}{c}\text { n.e.r. } \\
\text { Jap }\end{array}$ & $\begin{array}{c}\text { n.e.r. } \\
\text { U.S. }\end{array}$ & $\begin{array}{c}\text { infl. } \\
\text { Fra }\end{array}$ & $\begin{array}{l}\text { infl. } \\
\text { U.K. }\end{array}$ & $\begin{array}{l}\text { infl. } \\
\text { Jap }\end{array}$ & $\begin{array}{l}\text { infl. } \\
\text { U.S. }\end{array}$ & $\begin{array}{l}\text { MSCI } \\
\text { World }\end{array}$ \\
\hline $\mathbf{a}$ & 0.188 & 0.138 & 0.216 & 0.196 & 0.215 & 0.168 & 0.264 & 0.200 & 0.186 & 0.080 & 0.058 & -0.078 & 0.024 & 0.189 \\
\hline s.e. & 0.033 & 0.015 & 0.020 & 0.020 & 0.021 & 0.026 & 0.080 & 0.038 & 0.034 & 0.012 & 0.029 & 0.022 & 0.030 & 0.016 \\
\hline b & 0.956 & 0.992 & 0.963 & 0.961 & 0.953 & 0.981 & 0.663 & 0.938 & 0.932 & 0.994 & 0.991 & 0.995 & 0.916 & 0.960 \\
\hline s.e. & 0.016 & 0.004 & 0.008 & 0.009 & 0.011 & 0.008 & 0.121 & 0.022 & 0.025 & 0.004 & 0.018 & 0.006 & 0.170 & 0.008 \\
\hline
\end{tabular}

PANEL C: SPECIFICATION TESTS

\begin{tabular}{|c|c|c|c|c|}
\hline Hypothesis & LR-test & df & $p$-value & \\
\hline $\mathrm{H}_{0}:$ The price of market risk is constant & 10.003 & 3 & 0.019 & $* *$ \\
\hline $\mathrm{H}_{0}:$ The price of market risk is equal to zero & 24.170 & 4 & 0.000 & $* * *$ \\
\hline $\mathrm{H}_{0}$ : The price of nominal exchange rate risk is constant & 36.511 & 12 & 0.000 & $* * *$ \\
\hline $\mathrm{H}_{0}$ : The price of nominal exchange rate risk is equal to zero & 53.957 & 16 & 0.000 & $* * *$ \\
\hline Nominal exchange rate France & 15.146 & 4 & 0.004 & $* * *$ \\
\hline Nominal exchange rate U.K. & 23.388 & 4 & 0.000 & $* * *$ \\
\hline Nominal exchange rate Japan & 11.584 & 4 & 0.021 & $* *$ \\
\hline Nominal exchange rate U.S. & 13.468 & 4 & 0.009 & $* * *$ \\
\hline $\mathrm{H}_{0}:$ The price of inflation risk is constant & 118.495 & 12 & 0.000 & $* * *$ \\
\hline $\mathrm{H}_{0}$ : The price of inflation risk is equal to zero & 227.076 & 16 & 0.000 & $* * *$ \\
\hline Inflation differential France & 87.439 & 4 & 0.000 & $* * *$ \\
\hline Inflation differential U.K. & 41.219 & 4 & 0.000 & $* * *$ \\
\hline Inflation differential Japan & 60.208 & 4 & 0.000 & $* * *$ \\
\hline Inflation differential U.S. & 58.831 & 4 & 0.000 & $* * *$ \\
\hline
\end{tabular}




\section{Table 4}

\section{Summary statistics for the time-varying risk premia of market, nominal exchange rate, and inflation risk (1975-1998)}

This table depicts summary statistics for the time-varying risk premia related to the global market risk, nominal exchange rate risk, and inflation risk factors in the conditional model depicted in equation (3). The columns show the time-series average and the average of the absolute value of the various components of the expected returns on the equity indices of France, Germany, Japan, the U.K., and the U.S., as well as the risk premium decomposition of the expected returns on the MSCI world index. The table contains summary statistics for the full sample period 1975:01-1998:12 and separately for the first and the second half of the sample period. Table 3 presents the parameter estimates of the mean and covariance equations. Figures 2 and 3 show a graphical representation of the risk premia.

\begin{tabular}{|c|c|c|c|c|c|c|c|c|c|c|c|c|}
\hline & \multicolumn{2}{|c|}{ France } & \multicolumn{2}{|c|}{ Germany } & \multicolumn{2}{|c|}{ Japan } & \multicolumn{2}{|c|}{$\mathbf{U . K .}$} & \multicolumn{2}{|c|}{ U.S. } & \multicolumn{2}{|c|}{ World } \\
\hline & Mean & Abs. & Mean & Abs. & Mean & Abs. & Mean & Abs. & Mean & Abs. & Mean & Abs. \\
\hline \multicolumn{13}{|l|}{ 1975:01 - 1998:12 } \\
\hline Total risk premium (\% p.m.) & 1.22 & 1.22 & 0.75 & 0.76 & 1.14 & 1.19 & 0.80 & 0.91 & 0.86 & 0.89 & 0.96 & 0.97 \\
\hline Market risk premium (\% p.m.) & 1.25 & 1.25 & 0.90 & 0.90 & 1.44 & 1.44 & 1.58 & 1.58 & 1.54 & 1.54 & 1.48 & 1.48 \\
\hline Nominal e.r. risk premium (\% p.m.) & -0.56 & 0.56 & -0.10 & 0.19 & -0.25 & 0.34 & -0.92 & 0.94 & -0.49 & 0.58 & -0.44 & 0.45 \\
\hline Inflation risk premium (\% p.m.) & 0.53 & 0.57 & -0.05 & 0.26 & -0.06 & 0.27 & 0.14 & 0.35 & -0.18 & 0.22 & -0.08 & 0.19 \\
\hline \multicolumn{13}{|l|}{ 1975:01 - 1986:12 } \\
\hline Total risk premium (\% p.m.) & 1.39 & 1.39 & 0.95 & 0.97 & 1.30 & 1.41 & 0.96 & 1.17 & 1.20 & 1.24 & 1.20 & 1.24 \\
\hline Market risk premium (\% p.m.) & 1.36 & 1.36 & 0.91 & 0.91 & 1.49 & 1.49 & 1.85 & 1.85 & 1.72 & 1.72 & 1.63 & 1.63 \\
\hline Nominal e.r. risk premium (\% p.m.) & -0.82 & 0.82 & -0.03 & 0.18 & -0.24 & 0.40 & -1.29 & 1.32 & -0.33 & 0.50 & -0.40 & 0.42 \\
\hline Inflation risk premium (\% p.m.) & 0.85 & 0.90 & 0.07 & 0.30 & 0.05 & 0.34 & 0.40 & 0.49 & -0.20 & 0.27 & -0.03 & 0.23 \\
\hline \multicolumn{13}{|l|}{ 1987:01 - 1998:12 } \\
\hline Total risk premium (\% p.m.) & 1.05 & 1.05 & 0.55 & 0.55 & 0.97 & 0.98 & 0.64 & 0.65 & 0.53 & 0.55 & 0.71 & 0.71 \\
\hline Market risk premium (\% p.m.) & 1.14 & 1.14 & 0.90 & 0.90 & 1.39 & 1.39 & 1.31 & 1.31 & 1.35 & 1.35 & 1.33 & 1.33 \\
\hline Nominal e.r. risk premium (\% p.m.) & -0.31 & 0.31 & -0.18 & 0.20 & -0.25 & 0.28 & -0.56 & 0.56 & -0.66 & 0.66 & -0.48 & 0.48 \\
\hline Inflation risk premium (\% p.m.) & 0.22 & 0.23 & -0.16 & 0.22 & -0.17 & 0.20 & -0.11 & 0.21 & -0.16 & 0.17 & -0.14 & 0.15 \\
\hline
\end{tabular}




\section{Table 5}

The conditional model with time-varying prices of market, nominal exchange rate, and individual inflation risk (1975-1998)

This table depicts quasi-maximum likelihood estimation results of the conditional model in equation (4) over the period 1975:01-1998:12. Equity indices are from Morgan Stanley Capital International (MSCI). We construct real exchange rates versus the German mark from nominal exchange rates and CPI indices obtained from International Financial Statistics (IFS). We use the one-month euro-mark deposit quoted in London as the conditionally risk-free asset. Each mean equation relates the asset excess return $r_{i t}$ to the covariance with global stock returns $\operatorname{cov}\left(r_{i t}, r_{m t} \mid \Omega_{t-1}\right)$, the covariance with nominal exchange rate returns $\operatorname{cov}\left(r_{i t}, s_{l t} \mid \Omega_{t-1}\right)$, and the covariance with inflation rates in all $L+1$ individual countries $\operatorname{cov}\left(r_{i t}, \pi_{l t} \mid \Omega_{t-1}\right)$ (including the numeraire country $l=0$ ). The prices of risk are functions of instruments in $Z_{t-1}$, which proxy for the information set $\Omega_{t-1}$ that investors use in choosing their portfolios. The instruments include a constant, the dividend yield on the MSCI world index in excess of the one-month euro-dollar rate (WorldDY), the default premium in the U.S. (USDP), and the change in the U.S. term premium ( $\Delta$ USTP).

\begin{tabular}{|c|c|c|c|c|}
\hline Hypothesis & LR-test & df & $p$-value & \\
\hline $\mathrm{H}_{0}:$ The price of market risk is constant & 7.469 & 3 & 0.058 & $*$ \\
\hline $\mathrm{H}_{0}:$ The price of market risk is equal to zero & 59.555 & 4 & 0.000 & $* * *$ \\
\hline $\mathrm{H}_{0}:$ The price of nominal exchange rate risk is constant & 24.703 & 12 & 0.016 & $* *$ \\
\hline $\mathrm{H}_{0}$ : The price of nominal exchange rate risk is equal to zero & 97.273 & 16 & 0.000 & $* * *$ \\
\hline Nominal exchange rate France & 19.119 & 4 & 0.001 & $* * *$ \\
\hline Nominal exchange rate U.K. & 27.782 & 4 & 0.000 & $* * *$ \\
\hline Nominal exchange rate Japan & 14.811 & 4 & 0.005 & $* * *$ \\
\hline Nominal exchange rate U.S. & 21.495 & 4 & 0.000 & $* * *$ \\
\hline $\mathrm{H}_{0}:$ The price of inflation risk is constant & 97.361 & 15 & 0.000 & $* * *$ \\
\hline $\mathrm{H}_{0}$ : The price of inflation risk is equal to zero & 520.238 & 20 & 0.000 & $* * *$ \\
\hline Inflation level France & 150.598 & 4 & 0.000 & $* * *$ \\
\hline Inflation level U.K. & 11.004 & 4 & 0.027 & $* *$ \\
\hline Inflation level Japan & 24.503 & 4 & 0.000 & $* * *$ \\
\hline Inflation level U.S. & 155.725 & 4 & 0.000 & $* * *$ \\
\hline Inflation level Germany & 17.177 & 4 & 0.002 & $* * *$ \\
\hline
\end{tabular}




\section{Table 6}

QML estimates of the conditional model with time-varying prices of market, nominal exchange rate, and inflation risk (1975-2003)

This table depicts the results of a number of specification tests of the conditional model with time-varying prices of risk over the period 1975:01-2003:12. The model is estimated using quasi-maximum likelihood estimation. Equity indices are from Morgan Stanley Capital International (MSCI). We construct real exchange rates versus the German mark from nominal exchange rates and CPI indices obtained from International Financial Statistics (IFS). We use the one-month euro-mark deposit quoted in London as the conditionally risk-free asset. Each mean equation relates the asset excess return $r_{i t}$ to the covariance with global stock returns $\operatorname{cov}\left(r_{i t}, r_{m t} \mid \Omega_{t-1}\right)$, the $\operatorname{covariance}$ with nominal exchange rate returns $\operatorname{cov}\left(r_{i t}, s_{l t} \mid \Omega_{t-1}\right)$, and the covariance with inflation rates in excess of the numeraire inflation $\operatorname{cov}\left(r_{i t}, \pi_{t t}-\pi_{t t} \mid \Omega_{t-1}\right)$. The prices of risk are functions of instruments in $Z_{t-1}$, which proxy for the information set $\Omega_{t-1}$ that investors use in choosing their portfolios. The instruments include a constant, the dividend yield on the MSCI world index in excess of the one-month euro-dollar rate (WorldDY), the default premium in the U.S. (USDP), and the change in the U.S. term premium $(\Delta \mathrm{USTP}) . *, * * * *$ denote significance at the $10 \%, 5 \%$, and $1 \%$ significance levels, respectively.

\begin{tabular}{lrrr}
\hline Hypothesis & LR-test & df & $\boldsymbol{p}$-value \\
\hline $\mathbf{H}_{\mathbf{0}}:$ The price of market risk is constant & 2.321 & 3 & 0.508 \\
\hline $\mathbf{H}_{\mathbf{0}}:$ The price of market risk is equal to zero & 15.868 & 4 & $0.003 * * *$ \\
\hline $\mathbf{H}_{\mathbf{0}}:$ The price of nominal exchange rate risk is constant & 30.488 & 12 & $0.002 * * *$ \\
\hline $\mathbf{H}_{\mathbf{0}}:$ The price of nominal exchange rate risk is equal to zero & 46.215 & 16 & $0.000^{* * *}$ \\
\hline Nominal exchange rate France & 18.358 & 4 & $0.001 * * *$ \\
\hline Nominal exchange rate U.K. & 11.414 & 4 & $0.022^{* *}$ \\
\hline Nominal exchange rate Japan & 7.878 & 4 & $0.096^{*}$ \\
\hline Nominal exchange rate U.S. & 10.271 & 4 & $0.036^{* *}$ \\
\hline $\mathbf{H}_{\mathbf{0}}:$ The price of inflation risk is constant & 111.840 & 12 & $0.000^{* * *}$ \\
\hline $\mathbf{H}_{\mathbf{0}}:$ The price of inflation risk is equal to zero & 232.662 & 16 & $0.000^{* * *}$ \\
\hline Inflation differential France & 84.849 & 4 & $0.000 * * *$ \\
\hline Inflation differential U.K. & 45.276 & 4 & $0.000 * * *$ \\
\hline Inflation differential Japan & 70.047 & 4 & $0.000 * * *$ \\
\hline Inflation differential U.S. & 56.932 & 4 & $0.000 * * *$ \\
\hline
\end{tabular}


Figure 1

The prices of market, U.S. nominal exchange rate, and U.S. inflation risk, 1975-1998 The Price of Market Risk

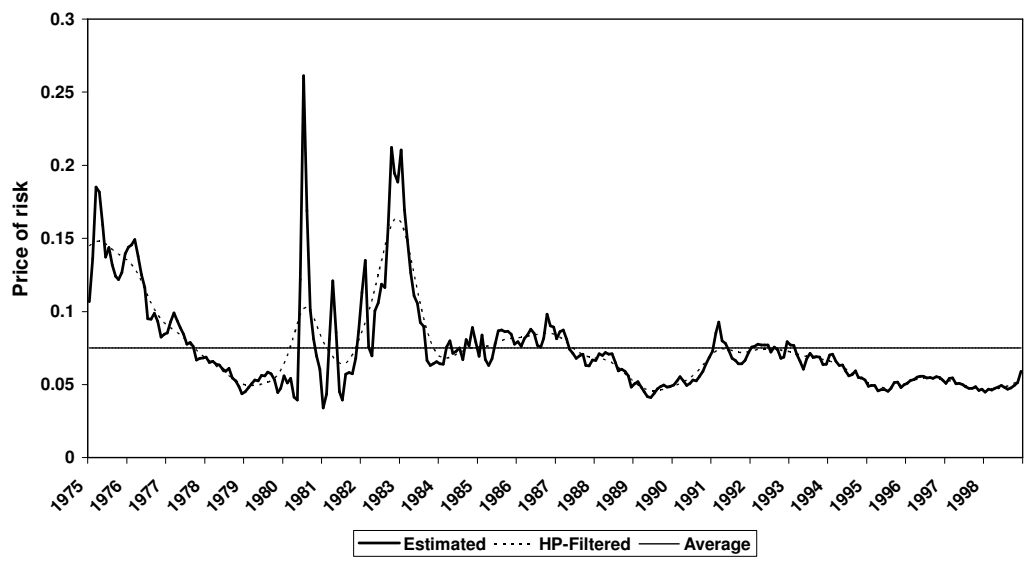

The Price of Nominal Exchange Rate Risk U.S.

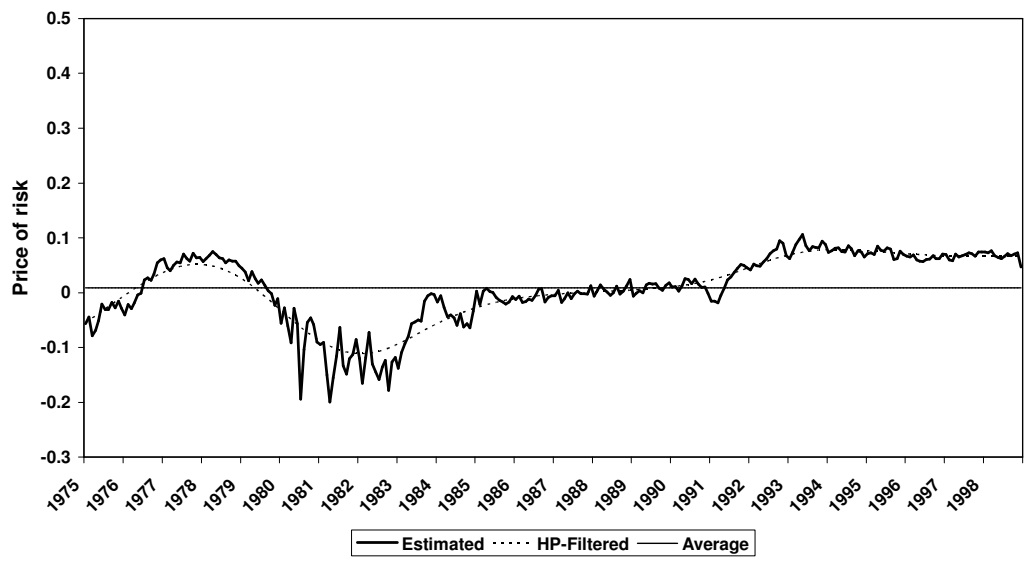

The Price of Inflation Risk U.S.

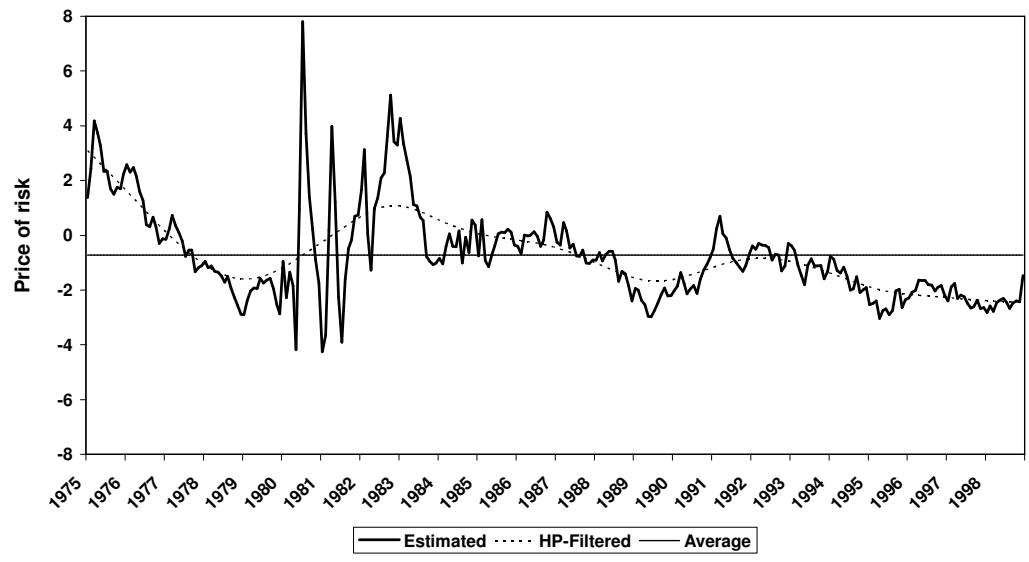


Figure 2

Estimated risk premia decomposition: MSCI Germany, 1975-1998

MSCI Germany: Aggregate Risk Premia

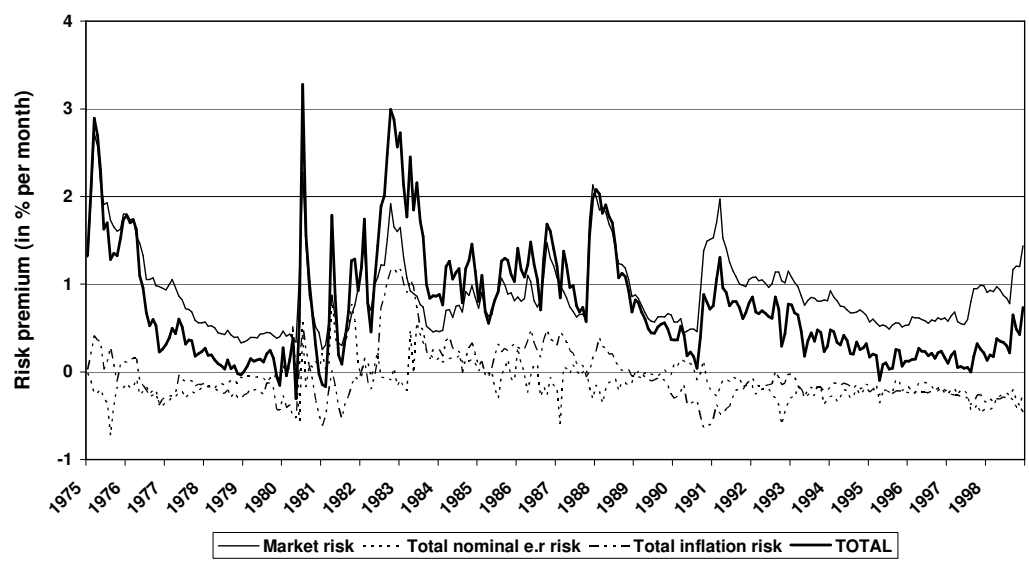

MSCI Germany: Nominal Exchange Rate Risk Premia

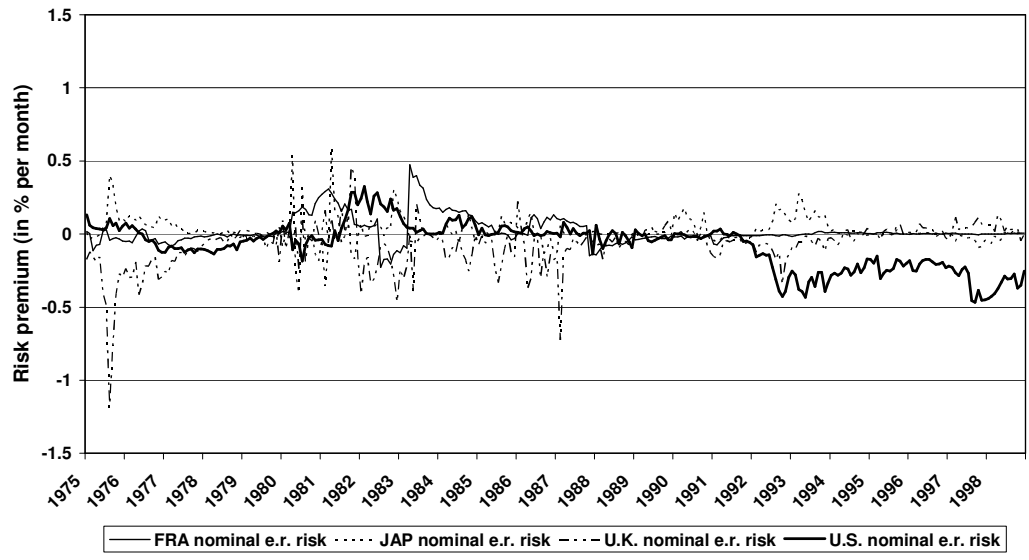

MSCI Germany: Inflation Risk Premia

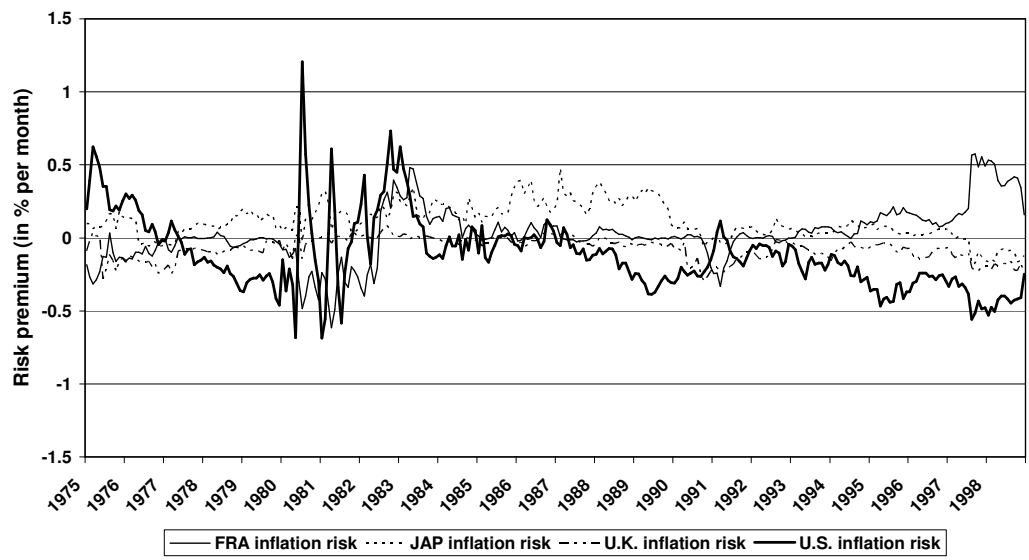


Figure 3

Estimated risk premia decomposition: MSCI Japan and U.S., 1975-1998

MSCI Japan: Aggregate Risk Premia

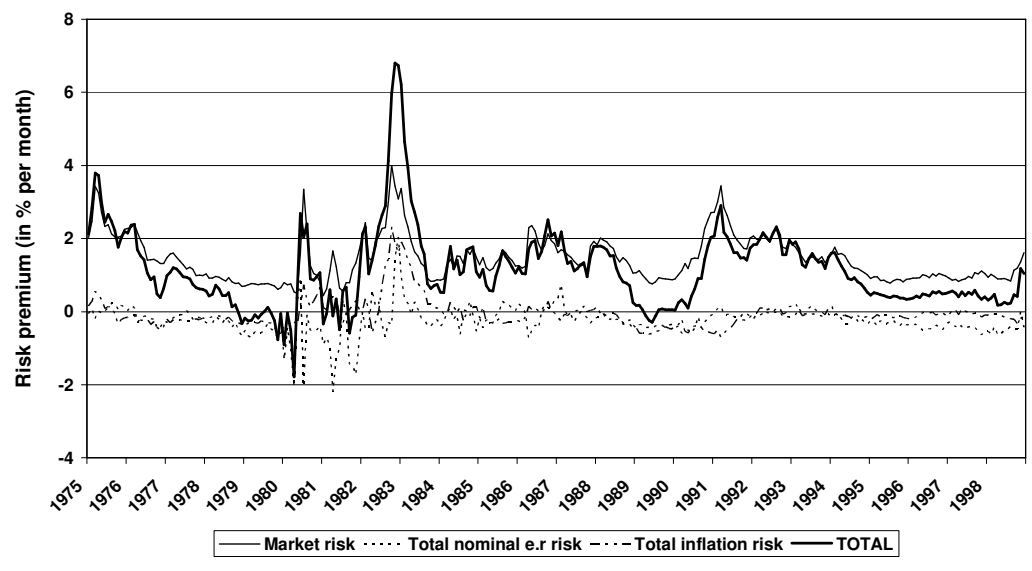

MSCI U.S.: Aggregate Risk Premia

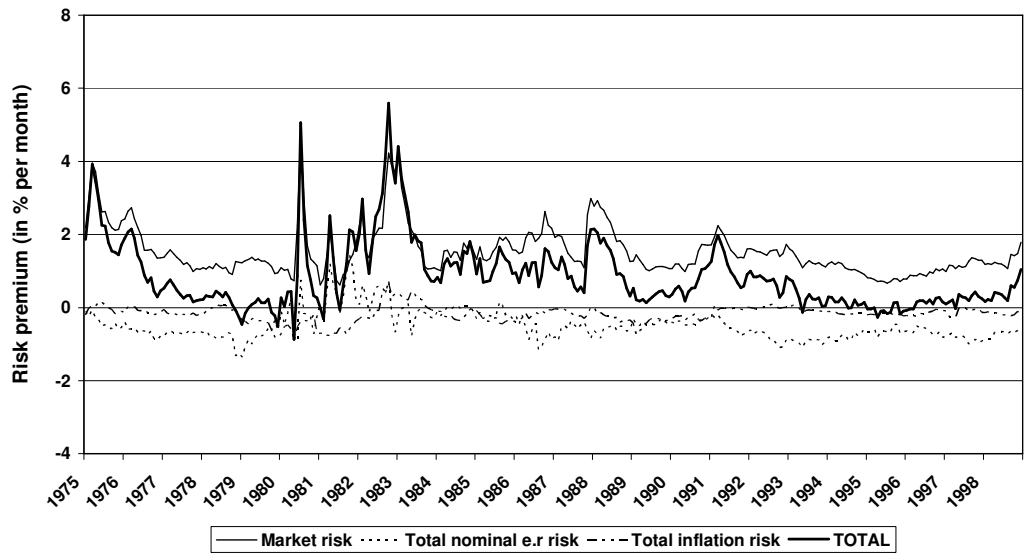

Figure 4

The price of French inflation risk over the full sample period 1975-2003

The Price of Inflation Risk France

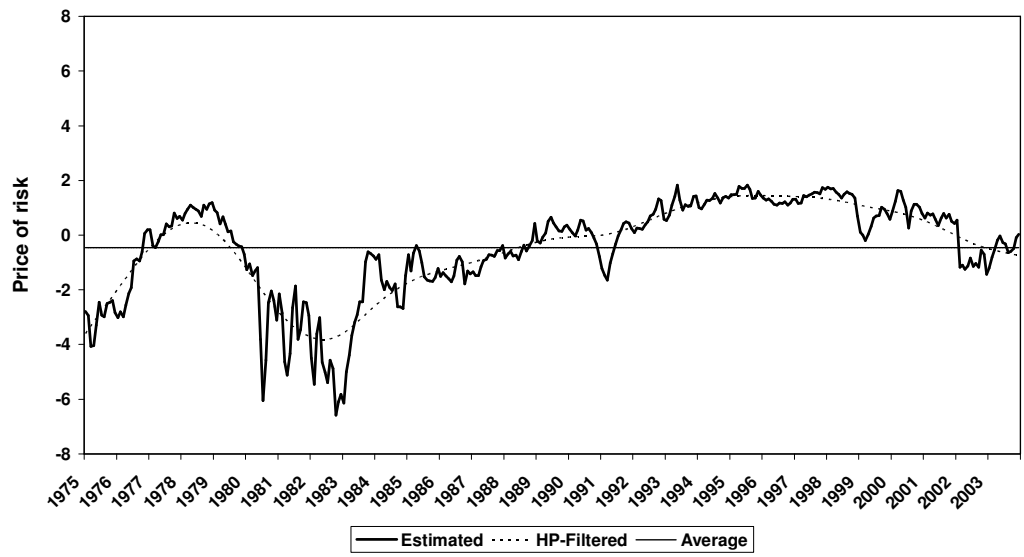

